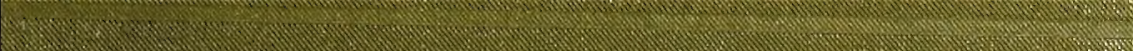
A. A. H H.M.

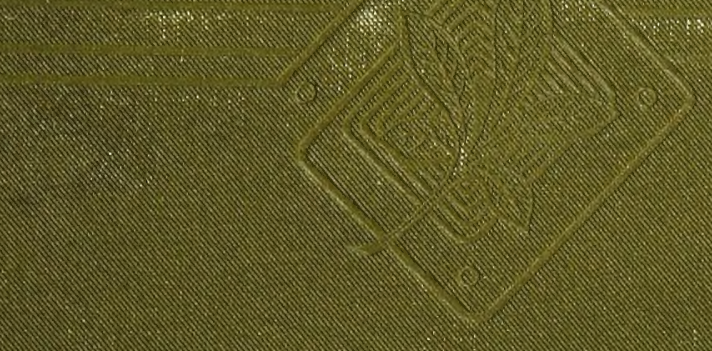

\&
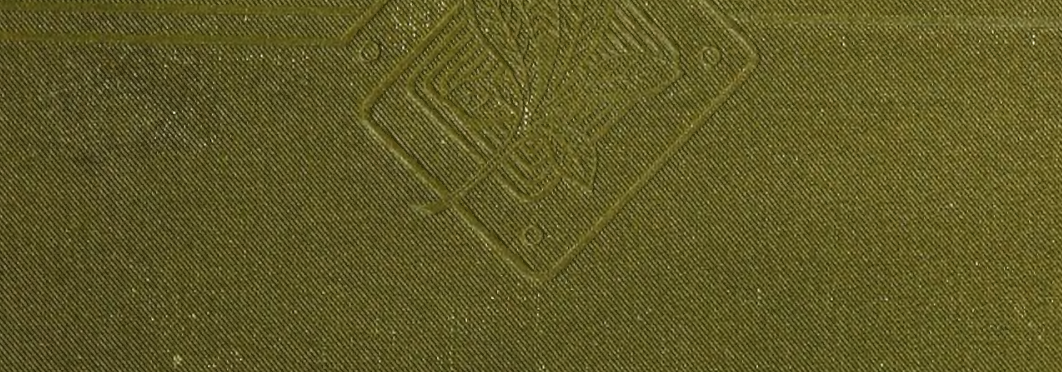

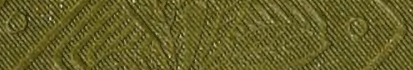




\section{LIBRARY OF THE, \\ HORTICULTURISTS' LAZY-CLUB. CORNELL UNIVER'SITY.}
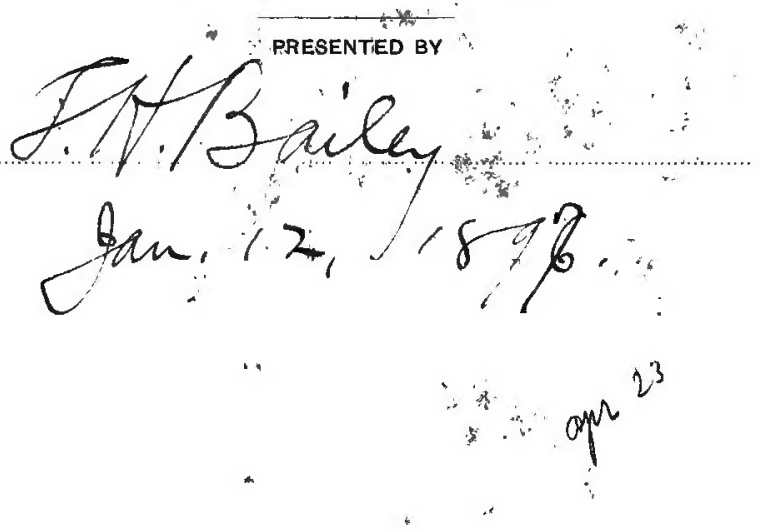

N. B.-Inscribe the date, post-office address, course af study, and the like. 


\section{Cornell University Library}

SB 363.B15

Field notes on apple culture.

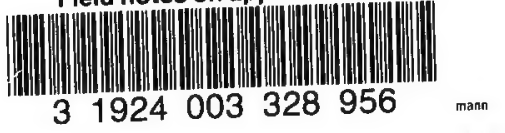




\section{Cornell University Library}

The original of this book is in the Cornell University Library.

There are no known copyright restrictions in the United States on the use of the text.

http://www.archive.org/details/cu31924003328956 



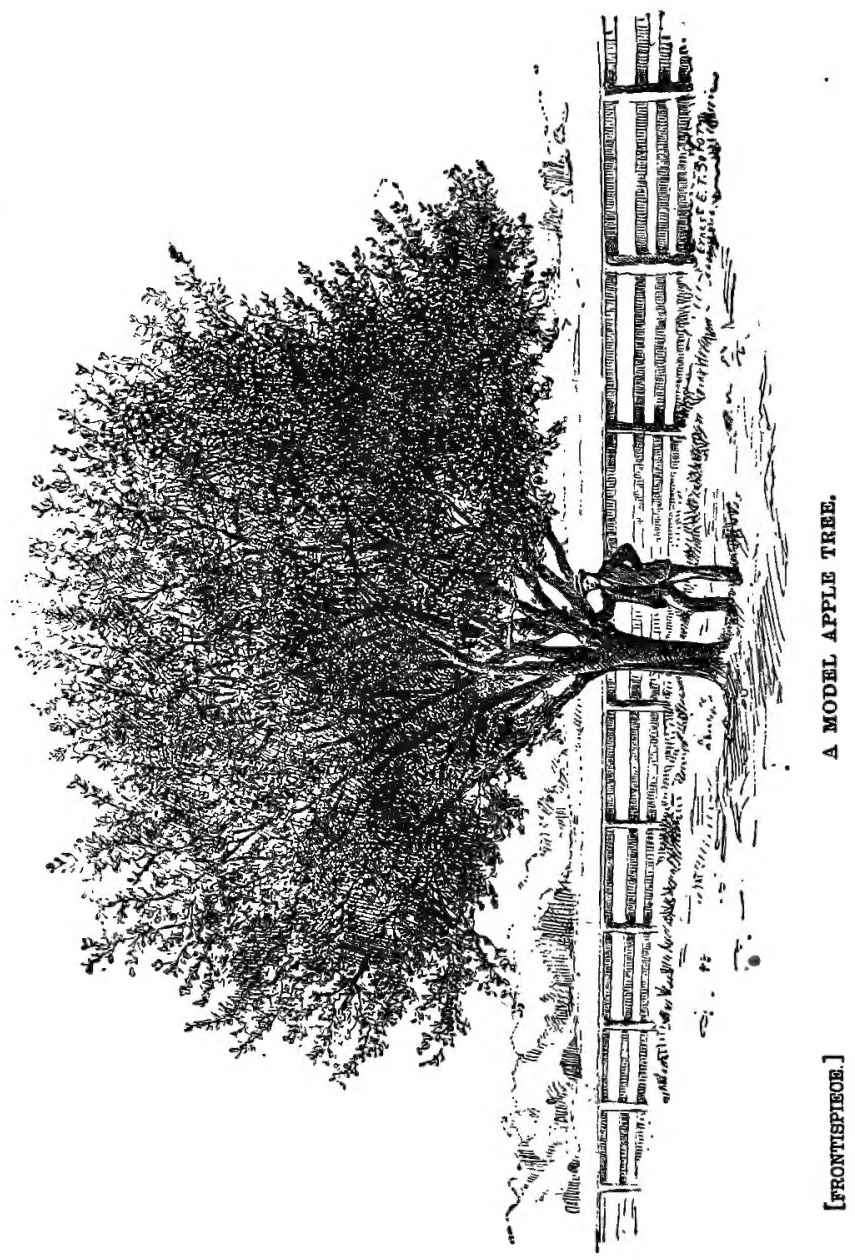




\section{FIELD NOTES}

ON

\section{APPLE CULTURE.}

BY

L. H. BAILEY, JR .

I. L U U S T R A T E D

NEW YORK :

ORANGE JUDD COMPANY,

52 \& 54 LAFAYETTE PLACE. 
Entered, according to Act of Congress, in the year 1886, by L. H. BAILEY, JR.,

In the Offce of the Librarian of Congresa, at Washington. 
To

Py Fiather,

THE RESULTS OF WHOSE THACHINGS

ART EMBODIED IN THESE PAGES 
These notes have been prepared with a view to afford a guide to those who would engage in apple culture. The teachings here conveyed are founded upon successful practice. The author has aimed to so guide the novice that mistakes may be aroided in the endeavor to reach piofitable results. Some of the papers have appeared in the "American Cultivator" and elsewhers.

$$
\text { L. H. B., JR. }
$$

Michigan Agrioultural College, Ootober, 1886. 


\section{CONTENTS.}

Chapter I.

Soil, Location and Windbreaks.

ChAPTER II.

Setting the Trees.-Distances

Chapter III.

When to Plant

Chapter IV.

Selecting Varieties of Fruit.

Chapter V.

Cheap Fruit Trees

Chapter VI.

How to Plow an Orchard.-Orchard Tillage 24

Chapter VII.

Manures for the Orchard 28

Chapter VIII.

Sod in the Orchard 31

Chapter IX.

General Notes on Pruning.-Forms of Trees 33

Chapter $X$.

High or Low Heads for Apple Trees 37

Chapter XI.

Training and Repaijing Orchard Trees.-Scraping39

Chapter XII.

General Notes on Grafting 45

CHAPTER XIII.

Top-Grafting Old Apple Trees 51

Chapter XIV.

Longevity of Apple Trees 54

CHAPTER XV.

Picking Fruit.-When to Pick 
Chapter XVI.

Packing Apples 59

Chapter XVII.

Profits in Apple Culture.-Shall We Plant More Orchards? -Losses from Theft 66

CHAPTER XVIII.

Winter Preparations 73

Chapter XIX.

Injurious Insects 75

Chapter XX.

Borers 79

Chapter XXI.

Codlin Moth 85

\section{L L U S T R A T I O N S.}

A Model Apple Tree Frontispiece.

Figure 1.-Tree-Placing Implement. . .

Figure 2.-Shoulder of a Limb ........

Figure 3.-A Short Ladder

Figure 4.-Twisted Branches in a Grotch . . . . . . . . . . . . 41

Figure 5.-Living Brace in a Crotch . . . . . . . . . . . . . . . 42

Figure 6.-Tree Prepared for Top-Grafting . . . . . . . . . . . . . 47

Figure 7.-Grafting Knife... $\ldots \ldots \ldots$

Figure 8.-Grafting Mallet _...

Figure 9.-A Scion........... _. 50

Figure 10, $\rightarrow$ Stub with Scions in Place $\ldots \ldots \ldots \ldots$

Figure 11.-Picker .......... 56

Figure 12.-Picker . . . .

Figure 1.3.-Hook . . . . . . . . . . . 56

Figure 14.-Beetle of Round-headed Borer ... . . . . . . . . . 77

Figure 15.-The Round-headed Borer . . . . . . . . . . . . 77

Figure 16.-Saperda Cretata . . . . . .

Figure 17.-The Beetle............ 83

Figure 18.-Flat-Headed Borer . . . . . 83

Figure 19.—Codlin Moth.......... 8 5 


\title{
FIELD NOTES ON APPLE CULTURE.
}

\author{
CHAPTER I.
}

SOIL, LOCATION AND WINDBREAKS.

As a rule, rather light or loamy soils, with deep and porous subsoils, are best adapted to apple growing. Natural drainage is imperative. Apple trees are impatient of wet feet. Cold and backward soils, even if well underdrained, do not give good results. I am not to be understood as discouraging tile drainage, but I prefer a soil naturally well drained to one tile-drained. Naturally drained soils are warm soils. I have in mind a contrast between two prominent Michigán orchards. Both were planted about twenty-five years ago, and with essentially the same varieties. One stands upon a rather poor sand, which possesses no decided subsoil higher than teu or twelve feet below the surface. The orchard has received good culture, but no underdraining, and the trees are to-day vigorous and productive. The other orchard stands upon a heavy loam, with a clay or hard-pan subsoil within two feet of the surface. The land has been remarkably 
well underdrained, and the trees have received good culture and an uncommon attention towards cultural experiments. Nevertheless, this orchard has never borne a good crop, and many of the trees have been winter-killed. $\sqrt{ }$ High lands are preferable for orchards, from the fact that they enforce atmospheric drainage. ${ }^{\circ}$ Cold air is heavier than warm air, and it settles on the lowest grounds. All have noticed the warmer air on the hills, when riding over a hilly country at night. $\checkmark$ Crops upon high or sloping lands escape frost, while those in the valleys are seriously injured. 'In still winter weather I have known a difference of ten degrees between contiguous places with a difference of thirty feet in altitude.

The aspect of the ground is sometimes important. ' If the locality is especially liable to late spring frosts a northern slope is to be preferred, since the trees will not start very early in the spring. Near large bodies of water, and in other places where there is no danger from late frosts, a southern slope is probably to be desired. Other things being equal, the southern slope will produce the highest colored and finest flavored apples. The same is true of a sandy soil.

There are many idle hillsides which would bear good apple orchards. New England is especially rich in such sites. As we approach the in riting, intensive husbandry of the future, we must begin to appreciate the value of many of our waste lands for orcharding purposes.

WINDBREAKS FOR ORCHARDS,

During a still, cold snap in a fruit-growing locality, when the mercury sinks to twenty below zero, it is the 
common remark, "There is no wind and the peach buds will not suffer." If the thermometer registers a temperature ten or fifteen degrees higher and a smart wind is blowing, everyone feels discouraged or uncertain. It is one of the commonest of observations that a wind increases cold. I recall a farmer who had an old and poorly made house, but who boasted that because he was well protected by trees he suffered less than a neighbor on a barren field, who had a new and tight house.

High winds are in several ways injurious to the orchard. It is a common and correct teaching that orchards should be planted on high land as a matter of winter protection, but, as such places are invariably windy, the idea has obtained that wind is in some manner a protection. The advantages to be obtained from high places are two: The soil, being commonly well drained, is warm; the atmospheric drainage is good. If we can secure the congenial soil and the atmospheric drainage at the same time that we avoid high winds, we secure the greatest requisite in orchard culture.

A high wind shortly before apples are ripe will shake off and bruise half or more of them in unprotected orchards. I have frequently known promising apple crops to be ruined in this manner. It frequently occurs that the trees are badly broken at the same time. An ice storm, followed by wind, is exceedingly destructive. Young trees set in an exposed situation are always being blown askew, and they must be repeatedly staked and tied. Many growers recognize this fact, and plant corn among young trees, but as soon as the corn is removed the unprotected trees are wrenched by Autumn winds. I frequently see 
old orchards whose crooked trunks record early damages from winds.

A good windbreak is the surest protection to an orchard. A windbreak may be made too dense, however. A walllike hedge of evergreens is apt to obstruct atmospheric drainage. A double or triple row of deciduous trees, with a few spruces intermixed, appears to be the most desirable. The best protected orchard I ever saw was one planted behind another orchard. The exposed orchard suffered much, however. If the hard winds are mostly from one direction the windbreak may not be needed on all sides. 


\section{CHAPTER II.}

\section{SETTING THE TREES.-DISTANCES.}

Care in setting the trees, as in all other operations in the orchard, is imperative. The shiftless orchardist cannot succeed. Thorough-going methods alone bring profit. Trees should make a good growth the first season. If they are weak during the first summer they will likely become the prey of borers, or they will dwindle for a few years and die. The first requisite in setting is to trim smoothly all broken roots. It is customary to cut off the ends of the roots in a sloping manner from the inside outwards, so that the wound will rest firmly upon the soil. It is not necessury that a tree possess many fine roots when transplanted. Such rnots are very liable to be broken in transportation, and when exposed they soon dry up beyond recovery. If a tree has a quantity of clean, bright roots the size of a lead pencil or larger, it ought to grow luxuriantly if other conditions are satisfactory. I am not sure but such trees do better than those with an abundance of fine roots, from the fact that the earth can be packed more snugly about the roots. I am not convinced that trees from a local nursery are preferable to those from a distance, unless one desires to remove a few trees with a ball of earth attached. With our rapid transportation trees can be sent a great distance without injury. To be sure, in the case of tender plants, such as peach trees, I should prefer trees grown in my own latitude. Some years ago, before railroads 
had reached Western Michigan, a box of apple trees was received from an Eastern uursery in very poor condition -so poor, in fact, that the roots were withered and the trees given up for lost. By way of experiment, however, they were thrown into a "cat-hole" and allowed to remain for several dars. Signs of life began to return and the trees were set among the logs in a clearing. Nearly all of them lived and flourished.

The soil in which the tree is set should be well pulverized. It is desirable to dig a hole three feet in diamater, unless the soil is in excellent condition, and then pulverize the bottom with the spade. Never make the mistake of making the hole smaller than the expanse of the roots. Let all the roots take their natural direction; never crowd them. Set the tree about as deep as it stood in the nursery. It is not at all important that it should face the same point of the compass that it did in the nursery row. Work the eurth about the roots with the fingers, and be sure that you leave no air space underneath the roots. There is no implement which can do the work of the fingers in setting trees. When the roots are covered, grasp the body of the tree and move it very slightly up and down two or three times to further pack the earth about the roots. Never use stones, clods or sods to fill in with. When the hole is filled, stamp the earth firmly about the tree.

\section{DISTANCE APART.}

Apple trees demand an abundance of room. For the larger sorts, as Tompkins King, Baldwin, Spy, and Greening, forty feet apart each way is none too much. 
I do not like the practice of setting peach and other trees between the apple trees, because they are seldom removed when they should be. Most people who begin growing small fruits in an orchard continue the practice too long. It has been my experience that it is safer to grow annual crops in the orchard than to grow other fruits. We are obliged to remove the annual crops.

If the orchard is to be of considerable size, I should survey it and drive a stake for every tree. If I did not survey it, I should measure around the sides and sight

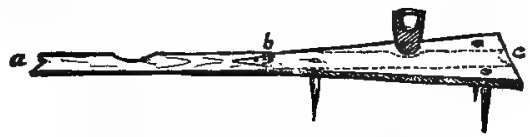

Fig. 1.-TREE-PLACENG IMPLEMENT.

across. I use an implement, represented in figure 1, for locating the tree in the exact place of the stake. It is held firmly in the ground by the three wooden legs, the notch at $a$ touching the stake. The arm, $a b$, is then turned back in the position $b c$, and the hole dug, after which the arm is turned down and the tree adjusted to the notch. An old spade handle is used as a handle, and if it is inserted so that the implement will balance in the hand, when the arm is turned back, one ean push the legs firmly into the ground with a single thrust. This implement (fg. 1) can be made out of light pine, with a length from $b$ to $c$ of two and a half feet and twelve inches wide across the end, $c$, and it need not weigh above six pounds. 


\section{H A P T E R ITI.}

\section{WHEN TO PLIANT.}

As a rule, fall planting is preferable to spring planting. The particular advantages of fall planting are two : the tree becomes somewhat established in the soil before spring opens; there is more leisure in the fall.

It is well known to nurserymen that cuttings of fruit or ornamental plants if set in the fall become callused on the wounded surfaces, and often senđ out small roots before freezing weather sets in. The same is true of fruit trees. A pear tree which is set as soon as the leaves fall will make rootlets in four or five weeks, if the weather is open. There is nearly always a beginning of the bealing process as soon as trees are planted in the fall. This healing, even though it be small, is a direct and important gain over spring planting. The tree also becomes thoroughly fixed in its place, the soil settles firmly about its roots, and it is ready to take advantage of the first opening of spring. The matter of greater leisure for planting in the fall is not an unimportant one. Trees should not be planted hastily. Time should be taken to pulverize the soil and to straighten each root. In the hurry of spring work this thorough planting is of ten neglected, and many times the trees are not set as early as they should be.

To insure success with fall planting the ground must be well drained and thoroughly prepared, and much care must be exercised in setting the trees. A poorly drained 
field is never fit for apple trees, and it is especially unfit for fail planting. . Trees must be set so firmly that winds will not rack and twist them. In severe climates fall p?'anting is often hazardous, although much care may be taken. The climates of Massachusetts and Lower. Michigan are not usually too severe for fall planting. It is only in much exposed places in our Northern States that it is to be practised with caution. We might say, in a general way, that north of Boston or Chicago fall planting may be regarded as hazârdous.

Spring planting is to be recommended in severe climates and in exposed places, and especially is it safest in stiff and heavy soils where the effect of freezing and thawing is disastrous to fall planted trees, and where the hardening of the soil prevents their roots from starting readily in early spring. Trees which are planted in the spring should be set as soon as the ground is dry enough to be worked. 


\section{H A P T E R I V.}

\section{SELECTING VARIETIES OF FRUTT.}

Whether an orchard returns a profit to the owner will depend in a great measure upon the kinds of varieties, and the number of each, which it contains. There is probably no greater mistake among orchardists than that of neglecting to give earnest thought to the varieties to be planted. Care in the selection of varieties is the first stone in the foundation, the first step to success. It is to the orchardist what the selection of the breed is to the stock-raiser.

There are several things to be taken into consideration in the selection of varieties. For profit, a fruit must combine these four qualities and preferably in the order named: hardiness, productiveness, beauty and good quality. These terms are all relative. An apple which is hardy in one part of the country may not be hardy in another part; the same is true of productiveness, and to a less extent of beauty and quality also. Hence, the subject of the selection of varieties must be a local question. The same fruit may not succeed in different parts of the same State. I have known good Sour Boughs to be raised successfully only sixteen miles from a place where they grew small, black and gnarly. If the grower has not had personal experience in his locality, the safest plan to pursue is to visit all the growers in the immediate vicinity, and to ascertain the most satisfactory varieties. Ask what fruits endure extremes of weather best, which ones bear the best, which are handsomest and best 
in quality, and which ones keep the longest. It is not necessary that experienced orchardists live in the neighborhood in order that this information may be secured. Select several of the most promising varieties grown by the neighbors, and as an additional guide write to the leading dealers of the market to which you will ship, asking what ones of your list will best meet the demand in the market. Experienced dealers' judgments are invaluable in this matter, but they do not, of course, cover the subjects of hardiness and productiveness. What dealers can sell best is not always what growers can raise best. Some apples are nearly cosmopolitan. Sueh, for instance, is the Baldwin, which is a superior variety from Maine to Michigan.

The varieties once decided upon, plant enough of each variety to pay for the handling and hauling. Fifty barrels of Gravensteins are worth as much as serenty-five barrels of mixed apples of similar size. Plant each variety by itself. It is a most exasperating operation to be obliged to pisk Baldwins first in one corner of the orchard and then in another. An orchard of five hundred trees, if set fus profit, should not contain more than five or six varieties, and, on an average, four of them should be winter apples. Three varieties are preferable to ten. I recall a story of a prominent poinologist, who, when asked what varieties he would plant in an apple orchard of one thousand trees, replied, "Nine hundred and ninety-nine Baldwins." When asked what the other tree would be, he replied, "I should m»ke that a Baldwin, too."

Hardiness is preëminently a relative term. The same 
variety will prove hardier upon a gravelly eminence than on rich bottom lands.' This statement is true of the Eastern States, at least. Of late, B. F. Johnson and Professor Burrill, of Champaign, Illinois, contend that the lower lands are generally preferable for apple growing on the prairies. On account of the pinching drouths the trees upon the higher lands cease growing by midsummer, but with the advent of fall rains they start into a second growth which does not mature, and, as a consequence, the trees are winter-killed. On the lower and moister lands the growth is said to be continuous and the wood matures thoroughly. In all cases, however, it is important to bear in mind the fact that hardiness depends as much upon soil and location as upon varieties.

Among the best market apples, are the following :

For Summer and Fall: Early Harvest, Sweet Bough (especially in New England), Red Astrachan, Williams' Favorite (eastward), Oldenburgh (Duchess of Oldenburgh), Alexander, St. Lawrence, Gravenstein, Maiden's Blush, Chenango (Chenango Strawberry), Twenty Ounce, Shiawassee (early winter), Ohio Nonpareil, Lowell, Porter, Hawthornden, Jersey Sweet, Fameuse (Snow Apple).

For Winter: Baldwin, Northern Spy, Rhode Island Greening, Ben Davis (West and South), Talman Sweet, Red Canada, Tompkins King, Grimes' Golden, Stark, Golden Russet, Roxbury Russet (eastward), Hubbardston (early winter), Fallawater, Smith's Cider, Jonathan, Nickajack (D̃outh), Vandevere, Peck's Pleasant, Limber Twig.

The following have a reputation for home use:

For Summer and Fall: Primate, Sweet Bough, Early 
Joe, Summer Rose, Fall Pippin, Fameuse, Garden Royal, Hawley, Keswick Codlin, Shiawassee, Alexander, Jersey Sweet, English Sweet, Dyer, Mother.

For Winter: Melon, Belmont, Swaar, Esopus Spitzenburgh, Jonathan, Hubbardston, Lady Apple, Yellow Newtown Pippin, Yellow Bellefleur, Northern Spy. Wagener, Rhode Island Greening, Pomme Gris.

Numerous improved varieties of Siberian crab apples are becoming popular, especially for our colder climates. The best known crabs are Transcendent, Hyslop and Whitney. The Russian apples are not yet sufficiently. known to be recommended. 


\section{H A P T E R V.}

\section{CHEAP FRUIT TREES.}

It is a common supposition that second-class fruit trees, if healthy and clean, make as good orchards as first-class trees. I once knew a grower to put the matter in this way: "Second-class trees have as good roots as any, and I can grow the tops to suit myself. They will cost me a third or more less than first-class trees of the same varieties, and I believe it will pay me to buy them." He did buy them and set them. They were peach trees, and as good as the ordinary run of second-class trees. Most of the trees lived. There were some two hundred of them. At the end of two years most of them were dead or dying. Borers had been imported with them from the nursery. The tops of most of the trees were weak or crooked, and many had to be cut back to the bud. The trees were given good culture, though not the best. About the third year after the trees were set I planted an orchard on the same ground, and of all the former trees but one solitary individual remained. This is a case of an experiment with cheap trees. It is probably an extreme case, but it does not convey too strong a lesson. I doubt if it ever pays to buy second-class trees. They may grow readily, but they do not make straight and clean trunks. I am aware that some nurserymen advertise their secondclass stock to be just like their first-class stock, only smaller. I have never seen such second-class trees, however. Of course the nurseryman cannot be particular 
about each individual tree of his lower grades. The lower grades contain his odds and ends-trees with gnarly trunks, those whose tops have been broken and sprouts trained up in their places, those with one-sided roots and weak growth. The orchardist cannot afford to buy them. They prove expensive in the end. It requires too much time and trouble to train them. In the case above mentioned the tops had to be cut from about half the trees, and a sprout encouraged. Usually more than one sprout started, and the unnecessary ones had to be rubbed off several times during the season. There is usually a crook where the sprout starts, and the tree does not always outgrow it entirely. In some cases all the. sprouts started below the bud, and a seedling was the result.

I must not be understood as recommending large and stout trees. I only contend for good trees. A thrifty peach tree one year from the bud is old enough for planting. It is much better than one three years old. A vigorous apple tree two years from the graft or bud is preferable to one twice as old. It should be demanded, however, that a tree be straight, vigorous, clean, and that it should have abundant and symmetrical roots. 


\section{H A P T E R VI.}

HOW TO PLOW AN ORCHARD.-ORCHARD TILLAGE.

Whether to plow the orchard to the trees each year, or to turn the sod in opposite directions in alternate years, must depend upon the soil and location. It is only in exceptional cases that the former course should be pursued. In poorly-drained orchards, on low, black land, this practice of heaping the sod about the trees bas the advantage of favoring drainage. Even in this particular, however, it is doubtful if the benefits will overbalance the inconvenience resulting from such a practice. Better tile-drain the orchard and keep the surface even. Drainage is not always secured by the deep dead furrows. The ground must have a good natural slope, or deep pools will be formed in the dead furrows just where the young roots demand warmth and drainage. The constant lowering of the dead furrows cuts off the smaller roots and drives them deep into the subsoil where there is little nutriment. The valuable surface soil is piled up about about the trees, where it does no good. Roots feed largely upon the valuable elements which leach down from the surface soil. The most active roots of large trees are far from the trunk. An uneven surface in an orchard is a constant source of aggravation, especially in picking-time, when one must enter with a wagon. Windfalls roll into the dead furrows, and become bruised, wet and decayed. 'The sod furrow does not usually strike close against the body of the tree. As a consequence, a little depression is formed there, into which drufts litter, form- 
ing an attractive home to insects and mice. There is no danger of injuring trees by plowing away from them and close to them, if one has trained his trees properly and if he exercises care. If the practice of close plowing be inaugurated in young orchards, the roots will start deep enoligh to aroid the plow. It is not necessary to plow deep. Trees should be pruned high. Low-headed trees are an abomination, and they present hardly any advantage over high tops. With moderately high-topped trees, short whiffletrees, low hames, a strap back-pad with leather turrets, a gentle team and a careful man, one need not fear about injuring trees. Plow one year east and west, the next north and south; one year to the trees, one year from them.

\section{ORCHARD TILILAGE.}

In the latitude of Bosto' and Chicago, cultivation in the orchard should cease before September. It is, perhaps, a good rule to stop the plow and the hoe a month before frost is expected. Late cultivation is always hazardous, and especially so in the case of young trees or of tender varieties. There is much room for an honest difference of opinion as to the condition in which the orchard should be left after a crop is removed. A highly successful friend maintains that the orchard should be left in weeds because they hold the snow. I should much prefer a perfectly clean surface to a weedy one. I doubt if snow is so valuable a covering about apple trees as some suppose. I even have my doubts as to its value in peach orchards. At tho best, it is a transient covering and it comes and goes 
during the winter. I have often made comparative observations on the effects of snow and no snow in the large peach orchards along the east shore of Lake Michigan, but I was never able to see any decided advantages of the snow protection. If the snow can be held without the expenditure of much labor, or withont running the risk of seeding the farm to weeds, then it may be desirable. If the orchard is not in sod, the most desirable fall treatment I have ever known is sowing rye early in September. The rye does not demand a deeply plowed soil, but the shallow plowing is sufficient to turn under weeds, and the subsequent growth of the grain will keep down those which may start. In the spring the rye may be plowed under early as a manure.

The whole question of how much and what kind of cultivation the orchard is to receive, will depend directly upon the kind of crops grown in it. If it is necessary to grow grain-wheat, oats or barley-in the orchard, year after year, the orchard had better be given up entirely. I never knew any profit to come from such an orchard. On the other hand, I would not recommend giving up the ground entirely to the trees for the first few years. In most cases the trees will receive just the cultivation that the crops which are grown among them receive, and, if no crop is raised, the cultivation of the orchard will probably be neglected. 'For ten years, or more, after apple trees are set, the soil ought to yield fair crops of potatoes, corn or garden vegetables, and the same is often true of a peach orchard for three or four years. In most cases it is a direct benefit to the trees to grow crops among them, and if a liberal amount of manure is used 
and the crop is harvested early, no possible harm can result. The best apple orchards I have ever seen yield remunerative crops of annual produce until the trees begin to bear heavily. 'The trees, however, are the primary care. I have no faith, as a rule, in the statements that fruit trees do not profit by cultivation. A farmer would not attempt to raise corn by planting it in sod and then mulching it, but many undertake to grow apple trees in this manner. The man who treats his orchard as he would his corn-field is bound to succeed.

Returning now to the particular kind of crops for an orchard, we will select first those which demand good culture throughout their growing season. Among such crops are potatoes, corn and garden vegetables. I know of no better crop than early potatoes. The overturning. of the ground at digging time destroys the late weeds and furnishes a good late summer stirring of the soil. In many places, especially at the West, corn is regarded as the bast crop for a young orchard, as it protects the trees from winds and keeps the ground cool. The protection from winds is rather an imaginary benefit, as the heaviest winds occur when the corn cannot afford protection. All the garden vegetables which are harvested by the first or the middle of August are excellent orchard crops, and in many parts of New England, at least, they are profitable when grown in large quantities. 


\section{CHA P T E R VII. \\ MANURES FOR THE ORCHARD.}

It appears to be a general notion that fruit trees do not require manure in the same proportion as other crops. The reason for this notion is apparent. Entirely neglected trees usually bear a moderate crop of fruit, at least once in two or three years, and not having cultivated and liberally manured trees to contrast with them, the grower does not see great need of manuring. To satisfy curiosity, let a person cultivate and manure a portion of a neglected orchard, and then note the comparative thriftiness and fruitfuluess of the cultivated and neglected portions. Lack of vigor in trees is one reason for their being attacked by insects.

The first step in the enriching of an orchard is good cultivation, as recommended in the preceding chapter. For good cultivation there is no adequate substitute. Barnyard manure is the best of all manures for the orchard in the general rim of cases. It cannot always be had in sufficient quantity, however, to supply the orchard or even a portion of it, as the fruit trees are commonly an entirely secondary consideration to grain and vegetable crops. If crops are grown in the orchard, the trees will obtain a part of the manure which is applied to the crop. It is a good plan to reserve a certain portion of the manure each year for the orchard and to apply it to different parts of the orchard in succession. It should be plowed or harrowed in in the spring. The old mistake of applying the manure close about the trunk of the 
tree should never be made. It is not advisable to feed horses by tying onts about their legs. There are very many refuse matters about the farm or in the neighborhood which can be composted. An intimate friend, who has the reputation of making everything into manure, has also the best fruit of any one in the neighborhood. From a shingle mill nearly two miles from his home he drew the shavings and used them as bedding. From the stable they went into the manure heap and from the manure heap into the orchard. A pile of sawdust three miles away was utilized in the same manner. Even cinders from the blacksmith shop went into his manure piles. He asked the privilege of mowing swales on his neighbors' farms. The weeds, brush and swale hay were obtained in quantities and stacked in the sheep yard. All winter this was fed to the sheep in abundance. They obtained balf their living from it, and the remainder was broken and trampled down. In the spring it was carted to the orchard. Even the fine brush, which was cut from the apple trees, often went into the manure. Such litter, after standing a year or more in a compost heap, with a number of turnings and the use of a little quicklime, will be entirely decomposed. In this manner utilize the refuse from the vegetable garden, the autumn leares, the brakes in pastures, and all other materials which can be made to decay. Of course the weeds should be cut before the seeds are ripe. If one keeps stock, this litter may be thrown directly into the stable or yard, to be broken and picked over by hogs, sheep and cows. This manner of disposing of litter produces a fertilizer little 
inferior to a compost, and it is less expensive. Few farmers realize how much fertilizing material annually goes to waste.

Wood ashes are an incaluable manure for the orchard. They may be used when leached or unleached. Unleached ashes should be used with caution. Leached ashes may be applied to the depth of two inches.

It is an absurd notion that manuring fruit trees is injurious. I have applied barnyard manure for years and never knew any injury to result. One must exercise judgment, however, as well as in the case of grain or other crops.

Green manuring is often to be recommended. Rye is especially good for a green manure in the orchard. It may be sown in the fall with a very little stirring of the ground and turned under the next spring. During the winter the rye holds the snow, which may give some protection. 


\section{CHA P'T E R III. \\ SOD IN THE ORCHARD.}

For the first eight or ten years after apple or pear trees are set, they demand cultivation with the plow and a liberal application of manure. After this the orchard may often be seeded down for a time to advantage. Whether or no an orchard should be seeded will depend upon the richness of the soil, the condition of the trees and the amount of manure or mold at the command of the grower. There is no general rule. If there is a doubt as to the expediency of seeding, it is best to cultivate.

If an orchard has been properly managed during the first ten years of its life the soil will be rich and in good tilth. 'The trees will be making a good growth, and they will present a dark and vigorous appearance. Such orchards will bear seeding down and they may profit by it. But even under these favorable conditions I do not believe that seeding should be permanent. Two or three years of June grass, orchard grass or clover should commonly be the limit, and dnring this time the sod should be closely pastured. One trouble with high grass in orchards is the increased liability to danger from drouth.

I have said that cultivation is always safe and profitable, and yet I have seen orchards on heary land which made prodigious wood growth and bore but little. When such orchards were seeded down, the growth was checked, and more fruit was the result. These are exceptional cases. Apples on cultivated trees are usually lighter colored than those on trees in sod. Highly colored apples are oftenest borne on slow growing trees. 
There are some cases in which seeding cannot be dispensed with, as in old orchards and on stony ground which cannot be plowed. One of the adrantages of good and persistent cultivation, as long as the orchard can be plowed, is to prepare soil and trees for the sodded old age which overtakes the tree at last and forbids the encroachment of the plow. Orchard grass is a general favorite for old orchards, but unless it is sown thickly and is fed down close it is apt to make "stools," or clumps. Nearly all soils will run into June grass, which makes a smooth and firm sod. Every two or three years apply a heavy top-dressing of any mulch or manure which is cheapest. Dressings of wood ashes are excellent. Straw is also one of the most desirable mulches. I have known a straw mulch a foot thick to decay and to pass almost out of sight in one year. Fallen leaves spread over the ground and held down by sedge or other coarse material are also excellent. The sedge and weeds which grow in bogs, if mowed early, before the seeds are ripe, may be used to advantage; also brakes, fine brush, sawdust, coarse horse manure-in fact, any material which can be spread over the surface to sufficient depth to keep the sod loose and which will decay speedily, is to be recommended. This mulch is to be applied only through the center of the spaces if sufficient quantity cannot be had to cover the whole ground. On many of the rocky hillsides in the Eastern States, where the plow cannot be used, trees could no doubt be grown at a profit with no other cultivation than an annual heavy dressing of manure. It should be remembered that old orchards can usually be plowed to within ten or fifteen feet of 
the trunk, especially if the trees stand a good distance apart, and this should be done every three years at least.

To summarize: As a rule, cultivate for ten years after planting and as long thereafter as possible. Short rotations of grass are not injurious when the ground has been enriched by tillage and manure and the trees are thrifty. When seeding is advisable or necessary, pasture closely with hogs or sheep-and apply liberal mulching and top dressing.

\section{O H A P T E I X.}

\section{GENERAL NOTES ON PRUNING.-FORMS OF TREES.}

Most people make too hard work of pruning. In this, as in other farm operations, the chief requisite to success is good judgment. It requires no science to enable one to prune an apple tree. The orchardist must at once and forever renounce the notion that he must trim his trees, that he must dress them up into symmetrical and formal shapes. He must prune. He must decide how long he will have the trunk and then, each year, cut out . superfluous branches. It is necessary that the trees should, if possible, be kept straight and evenly balanced, but it is not necessary or desirable to trim into regular forms.

I have always pruned in May or early June. Wounds made at this time heal more rapidly than those made in early_spring. It is commonly asserted that the removal of growing branches weakens the tree from the 
fact that so nrany leaves and so much young wood is destroyed, but I have yet to see any confirmation of this notion in practice. Pruning in February and March has its advantages, the most important of which is the greater leisure at that time. The fact that there is such a balance of opinion as to the relative advantages of early spring or late spring pruning, is proof that the advantages of either are mostly unimportant. From the facts that wounds heal sooner, that the work is pleasanter and that the brush handles easier, I have a preference for pruning just after the leaves appear.

There is a conspicuous shoulder or enlargement at the

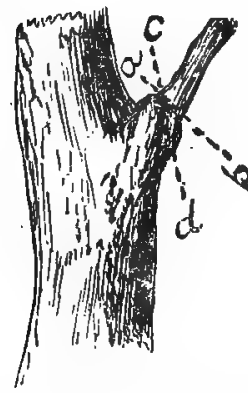

Fig. 2.--SHOULDER OF A LIMB. base of most limbs. It is just at the outer border of this shoulder that the limb should be severed. Cut at about right angles to the limb which you sever, and not to the trunk from which the limb springs. If cut at a right angle to the trunk the surface of the wound will be larger. This is illustrated in figure 2 . The line $a b$ represents the proper direction of cut, the line $c d$ an improper direction.

I have used many kinds of pruning tools, but for all purposes nothing is so good as a small saw in the hands of a nimble operator. A saw with a curved blade, with reflexed teeth for a draw cut on the concave edge and ordinary teeth on the convex edge, is handiest. Longhandled pruning contrivances are unfit for continuous work, as the constant looking up is very tiresome. For small twigs in the top of the tree nothing is so good as 
the ordinary small hand pruning shears and a pruning knife. I can work much faster and with less fatigue by getting into the tree with saw and shears, than I can by standing on the ground and using patent pruning tools. Of course I am now speaking of pruning an orchard. Upon isolated shade or ornamental trees the long-handled tools are convenient. I do not like heavy ladders. If step ladders are usech, they should be rery light. The best ladder is made of three rounds. This is long enough to enable one to get into the tree, or the legs can be crossed about the top round, as in figure 3 , if one must reach a limb where there is no support for the ladder. This simple ladder is in use among grafters.

Branches which are parallel with stronger horizontal

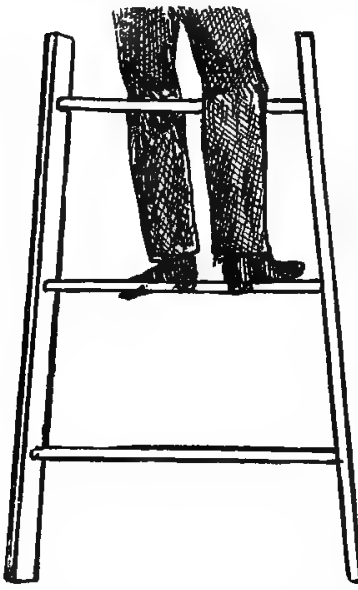

limbs should be removed. If two limbs rub, one should be cut out. The vigilant orchardist will cut out unnecessary limbs before they get large and troublesome. It is often said that one should never use any other tool than a knife in pruning an orchard; that every unnecessary limb should be cut before it is large enough to demand a saw. This condition of things is certainly a desirable

Fig. 3. $-\triangle$ SHORT LADDRR. consummation, but I do not believe that it can be done, unless the operator has little else on his hands than a hundred apple trees. I should not limit my pruning by the size of the limbs to be cut. 
In other words, I should remove every limb which ought to be removed, large or small. But it is a sign of a good orchardist if the unnecessary large branches are few or none.

\section{FORMS OF TREES.}

The idea is still current, as a result of old teachings, that some form of top for all the trees of an orchard must be decided upon before one enters upon the important duties of pruning and training. This shape, to which everything must be made to conform, may be the "hollow top," the " umbrella shaped," the conical, or the broad and flat headed. Whatever this uniform shape may be, it is at variance with nature, and does not recognize the peculiar and distinguishing forms of different varieties. It is by no means necessary that all the trees of an orchard should be trimmed into one form. 'A variety in the forms will heighten rather than decrease the beauty of an orchard. But an orchard is not supposed to be trained for beauty. The training must have for its object the production of more and better fruit, and the prolonging of the life of the tree. The best rule for shaping a tree-if a general direction may be called a rule-might be worded something like this: Let the top take its natural shape, keep it symmetrical, and cut out all interfering limbs. The Rhode Island Greening should be allowed to make its natural broad and flat head; in fact, it cannot well be made to take any other form. The strict and conical head of the Northern Spy should not be malformed. Under a proper and careful thinning out of some of the minor branches each year, 
one sort of top can be kept as symmetrical and as open to light as another. Half the difficulties of pruning are done away with when one decides to let the top take its natural form. If one attempts to shape his trees to some model he will be liable to constant disappointment and exasperation. He will find many trees stubbornly contrary. He will cut and train and worry for a few years, and find in the end that the tree has the mastery.

\section{H A P T E R $\mathrm{X}$.}

\section{HIGH OR LOW HEADS FOR APPLE TREES.}

This subject is entirely unworthy the controversy it has occasioned. Extremes in orcharding are as obnoxious as in other pursuits. It is evident that a top which rests upon the ground is a nuisance, and equally evident that one which is trained up beyond reach is scarcely less so. The head must be bigh enough to allow a team to work under it, and it must be easy of access for a man and basket. With a properly trained team it is not necessary that the limbs be much above their backs. It is a good rule to start the top high enough to clear a horse. At such a height, if properly pruned, the top should be easy of access.

It is an erroneous notion that a low top is the easier to pick from and to prune. It is easier to climb into a tree than it is to crawl under it and into it, with no room for standing up under it. It is also a mistake to suppose that low trees hold their apples better during winds. 
Low trees give as many wind-falls as high ones. The apples on the under side of these low heads are generally inferior. They are small, green, speckled and insipid. They get little sun, and, in consequence of dampness, they mildew. A very low tree is an abomination. I had rather have a very high one, if I could not have the golden mean.

It is a difficult matter to train some varieties into a a satisfactory head. The Rhode Island Greening is an unmanageable grower. At least some of the sorts of Greenings are; for Greening, like some other of our names, is one which covers a series of very nearly related sorts rather than one well-dcfined rariety. Some thirty Greenings were trained up to the height of a horse when they were young. Until they were fifteen years old they were pruned regularly and judiciously, but at the expiration of that time the lower limbs of twenty of them touched the ground. The ten remaining ones continued to hold their limbs horizontally, but in three or four years they began to drop. Some of the trees formed a perfect arbor, with a cool, still nook around the trunk and measuring from fifteen to twenty feet in diameter. On younger trees I tried many derices in the way of pruning to keep the branches upright, but sooner or later, with a few exceptions, their ends went down. A few show an upright habit, but I do not believe that they are true Rhode Island Greenings. There is no remedy for this provoking habit of the branches. The drooping can be delayed, and it will be less aggravating when it does appear, if the lower branches are made stocky. If all the side limbs are cut off for some distance, and a 
heary bush is left at the end of the branch, trouble is inevitable.

Baldwins, and other varieties in the same orchard, pruned in the same manner as the Greenings, but with less care, do not droop. Trees of a drooping habit should be planted on a dry and gravelly soil, and when they begin to cover the ground all tall grass and litter should be kept away from them. Dryness under the tree may then be secured. Perhaps it would help Greenings to top-graft them, although the most complete drooper I ever saw is top-grafted.

C H A P T E R XI.

TRAINING AND REPAIRING ORCHARD TREES.SCRAPING.

Aside from ordinary pruning, which is chiefly concerned with the form of the tree, there are certain matters of secondary importance and of occasional occurence which the pruner must not neglect. Young trees will be twisted by winds, or they may be entirely broken down; crotches will need to be strengthened and broken tops repaired. Repair is not necessarily associated with old age and decay. Vigorous apple trees can sometimes be repaired to as good advantage as can a strong wagon or sleigh.

If the grower has been so unfortunate as to secure weak and slender trees for planting, he must make them stocky by good cultivation and by heading back. Induce â vig- 
orous growth by a liberal application of marure, if the soil is not strong, and by frequently stirring the soil. Keep off all insects. It will not be necessary to cut the tree back to a mere stump, as is often done. After the proper form of the young top is decided upon, pinch back or cut off the tips of all the twigs, and repeat the operation during the whole season. If the tree has a very strong leader it may be necessary to cut it off entirely. If in a windy place, most slender trees will need to be staked. I do not believe in the advice of many that it is an injury to the tree to stake it. Some of the finest and straightest trees I know were staked for the first two years after being set. If staking can be avoided conveniently, it would, of course, be folly to resort to it. It is a good practice to stamp a sod firmly against the tree on the side towards which it leans. If the sod is large and properly placed, it will often answer all the purposes of a stake. There are two troubles connected with staking : the string or band is apt to gall the tree, and the stake protects the tree from the wind in one direction only. To avoid the galling, I have found it best to use a strip of ticking or flannel an inch or so wide, tied snugly about the tree. Such a band will yield enough to allow the trunk to expand with growth: Rye straw, when cut before the grain is ripe, makes excellent bands. A stake upon each side of the tree, witl a band tied across, will keep the tree in place much better than a single stake.

Trees which have been broken down by cattle, can often be saved by tying them firmly against a stout stake both below and above the break, and by thoroughly covering the 
injured surface with grafting wax. In cases of "barking," which is almost unavoidable in large orchards, I have found a good remedy to be a liberal application of cow dung, over which stout cloths are firmly wound. All the loose bark should be removed.

The disfiguring of the tops of trees by injuries from ice or wind, and by heavy loads of fruit, is a frequent occurrence. In this matter "an ounce of prevention is worth a

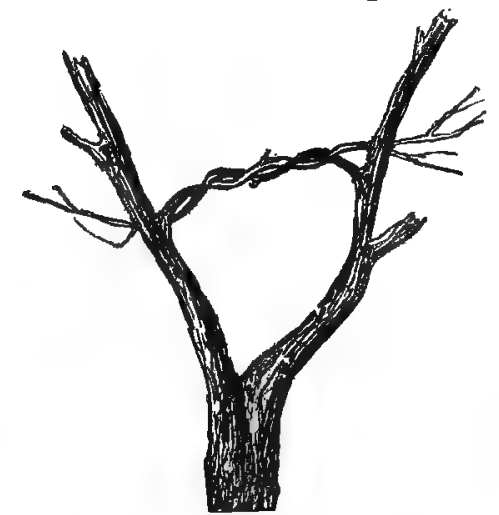

Fig. 4. - TWISTED BRANCEES IN A CROTCE.

pound of cure." In training young trees all crotches should be avoided. If the tree, as it comes from the nursery, has a fork, one branch should be removed and the other tied up perpendicularly. If bad crotches should occur in trees six years old or upwards, they should be braced. This bracing is done by twisting together two twigs, one from the inside of each branch of the crotch. The twigs may be twisted about each other loosely, the ends being allowed to project freely beyond the opposite branches of the crotch (figure 4). If kept in place, these twigs will soon begin to adhere along their whole length, aud after 
three or four years the free ends may be cut off. In a few years they will be united into a perfectly solid bar across the crotch (figure 5). Twigs from the size of a lead pencil to the size of one's finger unite most readily. All the larger crotches of an apple tree may be braced in this manner, and injury from splitting will be mostly avoided.

When a large branch shows signs of splitting, one can-

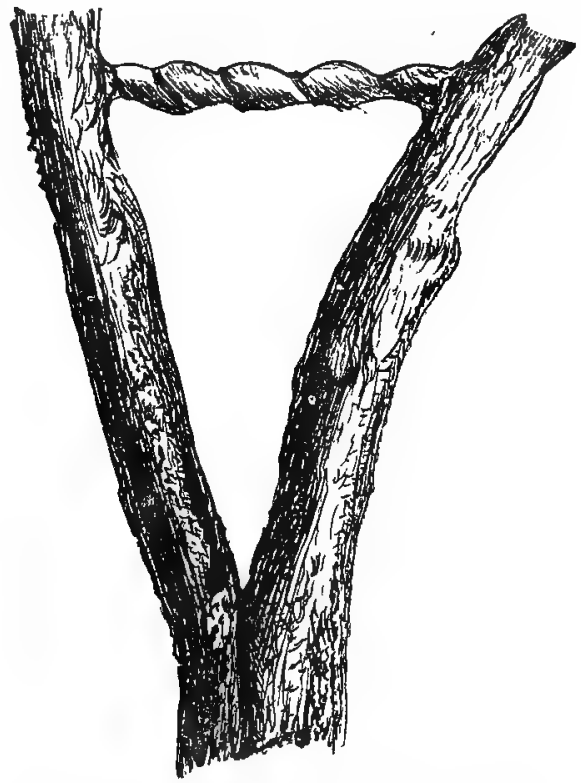

Fig. 5. - ITITING BRACE IN $\triangle$ CROTCH.

not wait for the growing together of small limbs. In such cases iron bolts must be used. Much damage to trees can be averted if bolts are used as soon as a weakness is discovered. Half-inch rods of considerable length may also be run through the branches at some distance above their junction. When crotches have been split entirely. 
apart, the branches may often be brought together again and secured with bolts. I will describe a case of unusual severity, which will serve to illustrate the method to be employed in repairing broken trees. An over-laden Baldwin tree, a foot or more in diameter, the top of which started about four feet from the ground, was broken down by a wind storm. The broken portion included nearly half the tree, and it split away from the main portion and lay flat upon the ground. The split reached to the heart of the trunk, and extended to the ground. Ropes were secured to the fallen portion, and were then passed around limbs on the standing portion, so that the broken part could be pulled up as with so many ropes and pulleys. Several men pulled up the broken half, and a three-fourths inch iron rod was passed through the body, and the two parts were brought snugly together by a heavy nut. Two rods, five or six feet long, were passed through the branches higher up, and were drawn tight by nuts. The heads of the bolts were large and flat, so that they could not be pulled into the wood, and the nuts had large washers underneath them. The split was then thoroughly waxed over and covered with a piece of rubber cloth. The two parts of the tree united, and in two years there was no evidence of a split except the bolts. Bands placed about trees to brace them are always injurious, as they restrict growth. I have never known injury to result from the use of bolts. The heads soon grow in, and no trace is left of them.

Large limbs often break down in such a manner as to preclude all possibility of rejoining the broken parts. The loss of the limbs may destroy the symmetry of the 
tree. In such cases one must keep the remaining portion of the tree cut back, and must train up the sprouts which spring from the wounded places to make good the missing portion. If such sprouts do not arise they can be made by the use of scions. Trim off smoothly the remaining broken ends of the branclies, and insert the scions between the bark and the rood, at a distance of an inch or two apart all around the wound. Scions for this purpose should be cut thin, with both edges of the bevel equal in thickness. As soon as the scions are set, wax over all exposed surfaces thoroughly, the same as for ordinary grafting.

If trees are girdled by mice or rabbits in the winter, some method should early be pursued to save them. The very first measure after the mischief is discovered is to protect the wounded surface by tying over it heavy rags, or banking earth against it. This keeps the surface of the wood soft, and prevents checking and drying by wind. It is useless to insert scions or to apply other remedies until the trees begin to start in the spring. Fresh cow dung plastered over the denuded surface, and tied on tightly with an abundance of cloths, will always save trees that are girdled before July, and it will usually save those girdled later. I have known no less than a hundred trees to be saved in this manner, and I do not recall a single failure.

\section{THE RAGGED BARK.}

The old and rough bark is probably some protection to trees in winter. It presents an untidy appearance, however. It is a safe practice to remove it in late spring. A much worn, thin hoe, with a handle two feet long, is 
a handy implement for scraping trees. It is never advisable to scrape to the "quick," so as to expose the live bark. Simply remore the loose shreds by a light pressure of the hoe. The remoral of this bark destroys lodging places of insects, and adds wonderfully to the appearance of an orchard. The person who keeps his orchard neat and attractive is usually successful. I know of no reason for whitewashing the truuks of trees, although the practice is a common one.

\section{H A P T E R X I I. \\ GENERAL NOTES ON GRAFTING.}

In most cases it is better to set trees which have been grafted in the nursery than to set seedlings, with the expectation of top-grafting them. If the variety of apple or pear is a good grower, a tree can be grown more quickly and more satisfactorily if grafted before being set in the orchard. To cut off a tree after it is three years old to graft it, is to put it back two years. It should be cut off and grafted when a year old, and the process should be done in the nursery. I am not sporking in the interest of root-grafting, but I wish to make it plain that time is lost by top-grafting trees, and, in the great majority of cases, no better trees are secured. In many cases there are decided disadvantages, besides the loss of time, in this top-grafting. When there is a great difference in the rate of growth of the stock and scion, there will be 
formed a disagreeable irregularity at the junction. If the stock is a much more rapid grower than the graft. there will be a sudden upward contraction at the point of union, or the opposite direction of contraction may occur if the graft grows faster than the stock. This irregularity in the trunk or main branches may not impair the vitality of the tree, but it is always unsightly and annoying.

It is a wise plan to avoid grafting as much as possible. There are few orchards, however, in which it can be entirely dispensed with. The most successful grafting is that which disturbs the tree the least and which leaves it the nearest like its original shape. The first rule to learn in grafting large trees is this: Graft many and small limbs. It is a good plan before cutting a tree to stand at some distance from it and to decide carefully at what distance from the body or from the center of the top the main limbs should be grafted to insure a good top. If a spread of ten feet each way from the center is decided upon, let all the main branches be grafted at about that distance. Figure 6 is a tolerable representation of this practice. Simply making the scions live is but a part of the operation upon old trees. One must plan for the future top of the tree. He must graft such limbs as should make permanent factors in the top he is building, and while he should avoid grafting too many limbs, he should likewise avoid grafting too few. It should be borne in mind that when a horizontal limb is grafted, the scion will grow upwards, and the breadth of the tree will not be much increased by subsequent growth. This is especially true of old trees. Trees ten years old, if prop- 
orly grafted, oíten overcome this fiult and make good horizontal growths. If a tree has been properly pruned, nearly all the conspicuous branches should be grafted. As a rule they should not be grafted where they exceed an inch in diameter. Some scions should be set on side

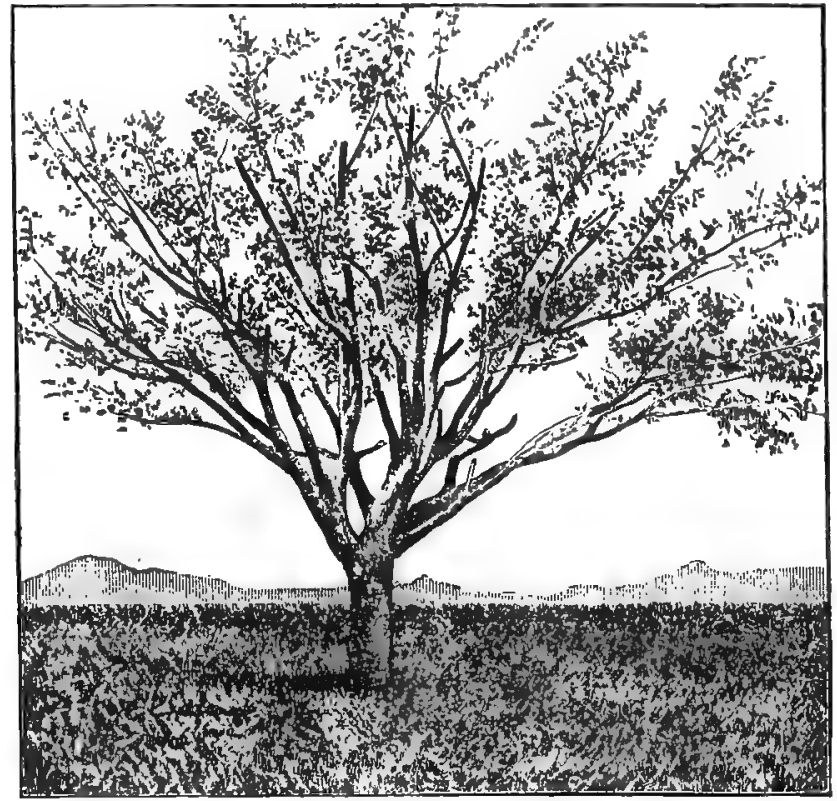

Fig. 6. -A TREE PREPARED FOR TOP-GRATTING.

branches of all the larger limbs, if the tree is large. Long, pole-like limbs should always be avoided. The old practice of grafting a few large stubs low down in the largest crotches, has nothing to recommend it. Even the plea of cheapness because fewer scions are set, is overbalanced by the injury to the tree and length of time required to change the top. I have seen many cases of this 
old style of grafting, and I think that in every case where the tree was fifteen year's or more old, bad results have followed. In some cases trees have died. In others the grower wisely concluded not to sacrifice all the large and handsome branches which were not grafted, and the trees soon grew up thick again on the old stock, and the scions dwindled or perished. In other cases the whole top had

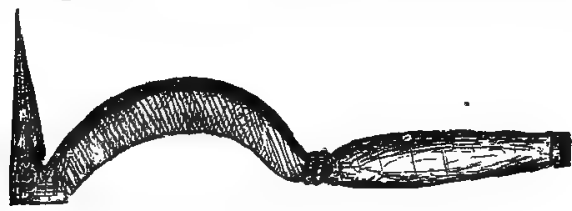

Fig. 7.-GRAFTING KNIFE.

to be grafted over again according to the newer methods. The kind of grafting most Jikely to be practiced in the orchard is that known as cleft grafting. The process is a simple one. In May, just as the leaves are pushing out vigorously, saw off the limb to be grafted where it is an inch or less in diameter; trim the edges of the "stub" smooth, and split it with a large knife, or a cleaver made

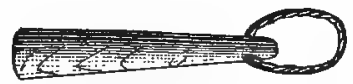

Fig. 8. GRAFTING MaLLET.

for the purpose. The best.implement for this purpose can be made from an old flat file by any blacksmith. Its shape is represented in figure \%. The curved cutting portion should span about five inches. The handiest mallet is made of a simple straight piece of hard wood, about fifteen inches long and hung over the wrist by a large loop of soft twine. This mallet is always in place for use and it is not dropping from the tree. It is shown in figure 8. Split the "stubs" horizontally. If you 
split them perpendicularly, and both scions grow, you will have one limb directly under another, which is always an inconvenient and ill-looking arrangement. The cleft should not be more than four inches deep at the most. The wedge of the knife is now inserted in the center of the cleft, and a scion is set on each side of the stub. When the scion is prepared ready for setting it should comprise about three buds. The lower end is cut wedge-shaped by slicing off each side of the scion with an even, smooth cut. On one side of this wedge-shaped portion should be left one of the buds. This outer edge is commonly left thicker than the inner, so that it receives a firmer pressure in the stub. Figure 9 represents a scion.

When the scion is set this bud will be deep down in the side of the cleft in the stub, and will be covered with wax, but being nearer the source of nourishment it will be the most likely of any of the buds to grow, and it will readily push through the wax. The scion is set into the cleft by exercising care that the inner surface of the bark on the scion matches the inner surface of the bark on the stub. A line between the bark and the wood may be observed. This line on the scion, in other words, should match this line on the stub. Figure 10 represents the stub just after the scions are set. Wax the whole over carefully and thoroughly. Do not leave any crack exposed. Wax which is pretty hard, and which must be worked and applied with the hands, is commonly best. For several years I have made grafting wax after the following recipe, and I have found it perfectly satisfactory : Two pounds of rosin, one pound of beeswax, one-half 
pound of tallow. Melt the rosin and wax together in a kettle, add the tallow, then pour a part of the melted mixture into a pail of cold water. As soon as it begins to harden, work with the hands until it gets nearly white. Keep the remainder of the mixture warm until all has

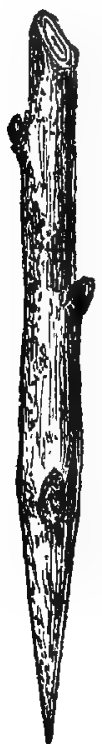

Fig. 9.—A scron.

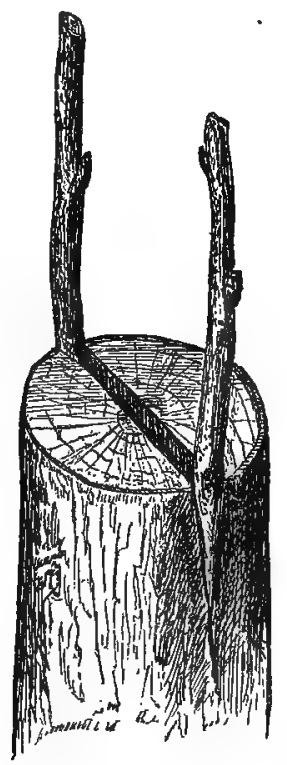

Fig. 10.-8тUB with sctons IN PLACE.

been worked over. Whenever the wax is handled the hands should be greased with tallow.

Scions are secured by cutting the vigorous last year's growth. " They may be cut at any time during winter. If cut in the fall it is not an easy matter to keep them in good condition all winter. If kept too dry they will shrivel ; if too wet they will sprout. I have had good success by tying them in bundles two or three inches in diameter 
and standing them half their length in moist sand in the cellar. I have also kept them in good condition by sticking them half their length into the ground about the base of the tree from which they were cut. If scions are cut in late winter or early spring, they can be kept better because they do not have to be kept so long. It is a common notion that scions cut in cold weather will not grow, but I have always had a contrary experience.

\section{CHAPTER XIIT.}

TOP-GRAFTING OLD APPLE TREES.

Top-grafting large trees is at best a harsh and unnatural process, and it should be practiced with caution. If an old tree bears moderately good fruit, a grower should consider well before top-grafting it. An apple below the average in quality often makes good pies, sauce or dried fruit. If the apples can be turned to any profitable use, and the tree is twenty years old, it is doubtful if it will pay to graft it. Much will depend on the thriftiness of the tree. A man who feeds his orchard, and prunes it regularly and judiciously, need have less luesitation about top-grafting. Trees receiving such treatment will stand a much greater chance of fully recovering from the shock of grafting. Much also depends upon the manner in which a tree is grafted. If a tree $h a s$ been properly pruned, nearly all the limbs may be grafted. If it has not, many beside the grafted limbs will need to be removed; and if the tree is old, and especially if a little feeble, it will be likely to suffer. A good grafter will try 
to leave enough small brush in the center of the tree to screen the trunk and large branches from the hot sun. I have often known trees to be seriously injured by sunscald, after having been severely pruned. A tree which will contain seven or eight stubs under the old system of grafting, will contain thirty or forty under the newer system. Two objections will at once be raised to this method : as grafters charge by the piece, it is expensive; it makes the top too high, and renders the main branches pole-like. To the first objection, I reply that no applegrower should hire a grafter; he should be able to do the grafting himself, or else his boys should do it. Every farmer's boy should learn to graft. Few occupations give more pleasure or yield a greater reward. To convert a wild and thorny tree into one bearing large and delicious fruit is a wouderful and fascinating process. The second objection is a more serious one. I have seen the larger branches of top-gralted trees entirely leafless for seven or eight feet, and crowned with a bush. Such trees are of course a nuisance, but they are due to a bungling grafter, not to the plan of grafting many limbs and small ores. There are enough side limbs on the average tree which can be grafted to correct this diffculty. If there shonld not be side limbs, some of the sprouts which start after the tree is grafted may be encouraged and grafted in a year or two. One must not expect an old tree to have as good a shape after grafting as before. It can sometimes be secured, but not often.

old and long-neglected trees which are to be grafted, may often be given a preparatory pruning for two or three years with profit. Unnecessary limbs can be better 
cut out before grafting than afterward; for after the grafting is done, and so much of the top removed, these limbs grow rapidly and soon show a marked increase in diameter. So much of the tree top will be removed in grafting, that the unnecessary limbs should not be cut away for two or three years or more, if they are large. It is not always an easy matter to prune a grafted tree properly. The ungrafted limbs must be gradually removed, and the grafts themselves must be trained. The ungrafted limbs should be annually cut away in about the extent to which the grafts grow, or a little mere. All suckers should be pulled off as they form during the season, unless there is noticed a tendency to sun-scald. The suckers may then be needed to shade the trunk and branches. I have known of a few cases in which nearly all the ungrafted branches were taken off the second year, without apparent injury to the tree, but I have known of many more cases in which such treatment has been ruinous. Improper pruning of top-grafted trees often results in an abundance of flat-headed borers. When the tree is weakened, borers attack it. I have several times observed the gradual weakening and final death of large trees which were severely top-grafted. I have so often seen ill results follow that $I$ wish to discourage the practice, unless all conditions are favorable. I have often grafted old trees when I was confident that they could never resist the operation, although their owners would not believe it until too late. If the tree is not perceptibly lessened in vigor, it is at least probable that it will be made a sprawling and unsatisfactory object. 


\section{H A P T E R X I V.}

\section{LONGEVITY OF APPLE TREES.}

"Why are apple trees shorter lived than they were when I was a boy ?" asked an old New England farmer. "I know of orchards which were set before I was born, and which are still in good condition, but my trees, set forty years ago, begin to show signs of giving out." The causes of this difference in the longevity of fruit trees are obviously three: the nature of the rarieties planted, the kind of culture given, and the increased severity of the winters. 1. Nearly all the old orchards are composed of seedling troos. Seodlings are hardier than most of the improved varieties. Wostward, and especially on the prairies, any particular variety is commonly shorter lived than it is in New England. It is probable that the varieties which have originated and have been long grown eastward are not adapted to the West. 2. High cultivation, with consequent heary crops, is a forcing process, and no doubt tends to lessen the longevity of trees. Trees which bear light crops of small apples approach the wild state, and are not worn out so soon as highly cultivated trees. High cultivation, judiciously applied, is not to be discouraged, however, for a short life, with an abundance of good fruit, is preferable to a long life with less and inferior fruit. 3. As the country becomes denuded of forests, the winter climate becomes more rigorous. As a consequence, many varieties which were formerly regarded as hardy are now destrojed. The 
Baldwin is one of the first to suffer. The remedy lies chiefly in growing windbreaks. Prairie climates are especially destructive, and any natural protection for the orchard should be eagerly sought.

\section{H A P T E R X V .}

PICKING FRUIT.-WHEN TO PICK.

I know of no pleasanter transition than that of turning from the elaborate stagings, ladders and fruit-pickers often described in fruit books, to the simple and easy methods of fruit harvesting practiced by successful growers. There are three things essential to safe and rapid apple picking : an ordinary light step-ladder, a couple of half-bushel, rourd bottom, handled baskets, with a book on the handles, and a smart boy who is not afraid to - climb. The ladder is the least essential article of the three. If trees are properly pruned, they will allow a man with a basket to enter the top. An ordinary iron hook will serve to hang the basket on a limb while it is being filled. Apple limbs are strong, and they will hold a boy or man more safely than is generally supposed. As a general thing, a boy is afraid to venture far, but a little training will enable him to climb well. Nor is it essential that the boy should be exceedingly young and. light in order to reach most of the apples on a high tree. It is quickness and agility, rather than lightness, that make a good apple picker. I know from experience that a young man of twenty-five can be of more service in an 
apple tree than any number of fruit-picking machines. Professional grafters do not depend upon elaborate ladders; they climb. The fruit picker should do the same. It may not be easy work, nor safe for fine shirts, but it is rapid and successful, nevertheless.

When one basket is full it is handed down and another

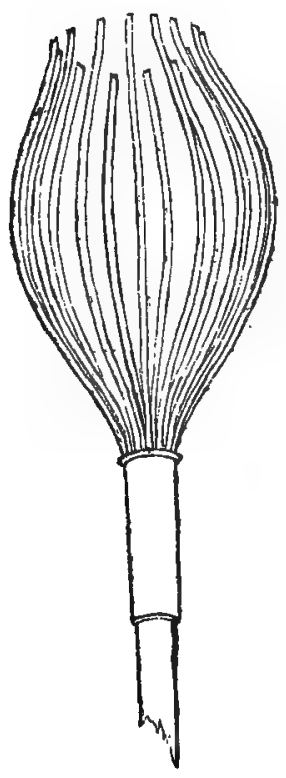

Fig. 11.-Picker.

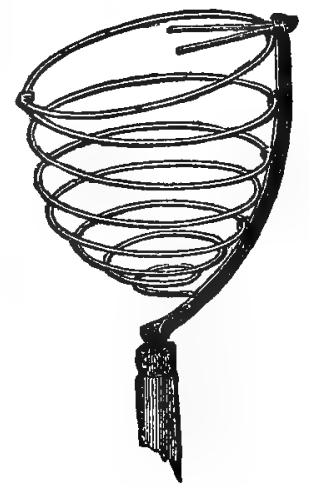

Fig. 12. - PTCKRr.

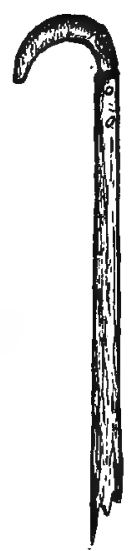

Fig. 13.-воOK.

one returned. A bag strapped on one's back, in the manner used for sowing grass seed, is usually a nuisance in a tree, although it may be handy on a step-ladder: The more one practices the more he will be surprised with his ability to reach apples on the ends of limbs. There will be some, however, which he cannot reach. If there are no apples on the ground, nor any wheat or oat 
stabble, these few apples may be shaken off with little danger. If a fruit-picker is to be used at all, here is the only place where it is necessary, in picking a few stray apples which have escaped reach or notice. For this purpốse a cheap and simple picker can be made by bending a stiff wire into the form of a circle six inches in diameter, with one side of the circle prolonged three inches into a $\mathrm{V}$-shaped projection. Upon this wire sew a cloth bag a foot or so deep, and fasten it to a pole by the end opposite the V-shaped extremity. This V-shaped projection will serve as a corner in which to catch the apple and pull it off, allowing it to fall into the bag. An excellent picker, as represented in figure 11, can be made from stiff wire by a tinner. The span across the top should be about six inches, and the depth from eight to ten inches. 'The wires should not be more than a half inch apart at their tips. The wires being more or less flexible, the apple is apt to draw through them if they are not close together. Care should also be taken to have the implement made as light as possible. A bungling mechanic will probably use too much solder. Another good picker is pictured in figure 12. It is patented. This implement is light, durable and pleasant to handle. When an apple lies close to a limb, however, it is much more easily removed by the former device than by this. A simple flattened hook with a thin, almost cutting edge, secured on the end of a pole (figure 13) is often handy for pulling off stray apples. This is the best implement with which I am acquainted for thinning apples. One of the most successful orchardists I know makes two or three tours of his orchard every week in 
July and August, and hooks off the wormy and illformed apples. A drove of hogs follow him and devour the apples and worms. I shall refer to this practice again. in the discussion on the codlin moth. This practice of thinning fruit is a profitable one, especially in the iustance of such heary bearers as the Baldwin. If the tours of the orchard are frequent, the work of thinning is not burdensome.

WHEN TO PICK.

In general, it may be said that winter apples should be picked when they are ripe. Ripeness is shown by the color of the apples, and by the ease with which they part from the tree. When sound apples begin to fall, they are ready to pick. Apples keep longer when picked before they are ripe, but such apples never possess the rich flavor and the crispness of fully matured fruit. Sound apples do not decay until they are over-ripe. Immature fruit ripens slowly during the winter, and does not soon reach the period of decay. It never ripens fully, however, and it is therefore always inferior. It withers and becomes tough.

While mature fruit will decay sooner than immature fruit, it is nevertheless much more preferable. Longkeeping qualities are certainly inferior to good eating qualities. Any treatment which retards the over-ripening of mature fruit will increase its long-keeping qualities. Keeping the fruit in a cold place is the best ordinary preventive of decay. Fruits which are over-ripe when harvested have already entered upon the period of decomposition, and they cannot be expected to keep long. Therefore, avoid the extremes. I never knew Baldwins and. 
Northern Spys to keep so well as when picked near the middle of October, after half the leaves had fallen. Professor Lazenby reports an experiment in picking Baldwins at different stages of maturity. Those picked early kept long, but wilted. Those picked when fully matured kept well and were excellent in quality. Those picked late kept poorly.

\section{H A P T E R X V I.}

PACKING APPLES.

It matters little how thoroughly the grower may have cared for his trees and growing fruit, if he does not exercise the same or even more scrupulous care in the handling and marketing of his crop he will fail to obtain a profit. Care in harvesting and marketing is fully equivalent, probably much more than equivalent, to all the other labors of the year combined. Still, it is a patent fault with our orchardists that this part of their business is not studied closely.

Apples must be handled with care. "Handle apples as you would handle eggs," is good advice. Do not shake them from the tree. When a basket is handed down from the tree another is returned, while the apples in the basket are sorted. The sorting is easily done by havung an empty basket at one hand into which the choice apples are placed, while the culls are placed in a pile on the ground. An experienced man can sort rapidly and accurately. The choice apples are commouly placed di- 
rectly in the barrel. Only clean barrels should be used. old flour barrels, unless carefully washed and dried, will usually impart a musty flavor to the fruit before midwinter, especially if the air in the storage cellar is moist. The first apples which are put in market barrels should be "faced." The facing consists in placing two or three layers on the lower head with stems down-that is, with stems pointing towards the head. Clean, bright apples of ordinary size should be selected for this purpose. The rest of the apples may be poured into the barrels. This pouring, if properly done, will not injure the apples. Eggs can be poured. Use a basket with a swinging handle, one which can be lowered into the barrel and turned while there, and hold the apples back with the hand so that they will not pour out too rapidly. Two or three times during the filling, shake the barrel gently to settle the apples firmly. Face the upper head in the same manner as the lower one. It is desirable not to head up the barrel at once. Cover with boards to keep out rain, and let the barrels stand open four or five days. It is not always possible to cover the barrels, however, in which case they may be headed up at once and turned down on their sides. In this position they will shed water. Thus far I have spoken of packing out of doors. The best results are always secured under cover. A cheap shed which will not leak is sufficient. It should be erected in a cool and shady place, as on the north side of a building. The apples can then be carted to the shed in the baskets, just as they come from the tree, in a spring wagon. If baskets cannot be had in sufficient quantity, the apples can be emptied from the pickers' 
baskets into small boxes in the wagon. Excellent boxes for this purpose are empty grocer's boxes which will hold about a bushel, or the contents of two baskets, and still rot be.so full as to prevent other boxes being set on them. A hole should be made in each end large enough to admit the hand. Such boxes can be handled with dispatch. From these the apples can be sorted into barrels and the barrels can be headed up at leisure. It is imperative that the apples should not rattle in the barrel after it is headed. Apples shrink a little after they are barrelled. They will usually sweat, also. Therefore, delay the heading up for some days. The barrel should be rather more than full when the head is put in. If the upper layer of apples is considerably bruised, no harm will result, especially if the head is soft wood, so that the juice is readily absorbed. It is better to jam these apples severely than to allow those in the interior to rattle. If the heading is done in a building, a lever press of simple construction does good work, but it requires two men, one to press and one to adjust the head. A lever press is nothing more than a lever under a girt with the barrel for a fulcrum. The ordinary screw press is troublesome. It persists in twisting to one side as soon as strong pressure is applied. This may be remedied by having the iron standards thick and stiff and by securing a long set in which the screw shall work. If this set or thread is four or five inches deep, and if the wooden cross-bar in which it rests is correspondingly thick and heary and well secured to the iron standards, the press should do good work. I have never seen such a press for sale; it must be made to order. 
Great pains must be taken in the sorting. Few people are aware of what constitutes a first-class apple. Such an apple must not be immature, over-ripe, wormy, or otherwise injured in any part, scabby or bruised. Very small apples from the interior of the tree are usually immature. Large and highly colored apples are apt to be wormy, over-ripe, or of poor quality. With some experience, ore can be able to tell a first-class apple by its feeling. First-class apples should not have their stems pulled out. Second-class winter apples can be put upon the market at once for immediate consumption.

Winter apples should be picked in cool weather, and they should be bandled on the shady side of the tree. A detached apple will ripen very rapidly in the warm sun, and its keeping qualities will be impaired. In order to keep apples, bear in mind the fact that they must be kept cool. If one has not a good apple cellar, he should store them in a shed until cold weather, or in any cool building which has windows opening to the northward and none to the south ward; in short, put them anywhere where they will keep cool. If the apples begin to assume a yellowish cast, they are getting too ripe. An atmosphere may be too dry, but a decidedly moist one is equally dangerous. Some cellars keep apples well, but most of them do not. The fruit cellar should be deep, cool, clean, well ventilated, and should have a northern exposure. A cellar which is stoned up in a gravelly soil, with a brick or gravel floor, should keep apples well. Keep the north windows open until there is danger of freezing. Shut them up on wet days. Water will freeze before apples will. If a person has a good cellar for 
keeping fruili, whe apples may be taken to it as soon as they are picked. It is an excellent plan to store apples on shallow shelves in cellars if one has the room and does not care to barrel them for market until spring. They can then be sorted at any time. Cider apples should be left on the ground in piles. They will lose some of their water and will make better cider. If they freeze a littlo on top they will not be damaged.

If the house cellar will not keep apples well, or if the quantity of app'es to store is large, a fruit cellar should be built at some other place. Mr. Horace Rainey details his experience in keeping apples for market at Columbia, Tennessee, in the "Spirit of the Farm," from which I extract as follows: "In the fall of 188\% I excavated a space eight feet deep, eight wide, and sixty feet long; this I walled up and arched over with a nine-inch wall of brick. Orer the arch I put a coat of cement, and over this I placed all the earth from the excavation, and at intervals in the arch of four feet I built small brick chimneys, or ventilators, which came out above the ground. I also made ventilators in each end. The door I placed in the north end. The floor I also laid of brick. The cellar being completed, the next question is to properly store the apples in it so as to economize in space.

"I had made several hundred slat-boxes or crates, each tc hold one bushel. These I carried to the orchard and left as many as necessnry under each tree. Each picker is provided with a small basket and a ladder, and is required to leave off his shoes or to wear rubbers; to handle the apples carefully, and to place them carefully, one at 
a time, in the boxes. The boxes are hauled in springwagons to the cellar, and placed one above the other up to the top, leaving a narrow passage down the center, so as to enable me with a lantern to examine their condition at any time.

"The advantages of the slat-boxes are many; the principal ones are thorough ventilation, economy in space, and ease of handling; and when ready for market, I nail a few slats on the top, and the apples are ready to ship. The boxes are much cheaper than barrels, and if the apples are highly colored, they sell much better than in barrels.

"The cellar being completed and filled, I watched the experiment with a great deal of interest. I gathered the apples from October 20th to November 10th, according to the variety, and about December 15th I overhauled them, and less than one per cent. were unfit for market. On February 1st I overhauled again, preparatory to placing on the market. I found about two per cent. unfit to ship, and this two per cent. was sold for more than enough to pay the expense of overhauling. The apples paid from $\$ 1$ to $\$ 2.50$ per box, according to variety, size, and color.

"The temperature of the cellar raried but slightly. During the winter of 1882-3 the lowest was thirty-eight degrees, and the highest was forty-seven degrees; and the past winter, which we all know was extremely severe, the lowest was thirty-six degrees. **** Now, after the second winter's test, I am glad to say that the cellar has sustained its well-deserved reputation, for, up to June 1st I had seven varieties in a good state of preser- 
vation. * * * * It more than paid for itself the first season. In addition to an apple-house, I use it during the summer months for milk and butter, vegetables and fresh meats."

Apples can be buried, something after the manner of potatoes, with good success, but they usually decay rapilly after removal from the pit. They usually keep well if buried after they are barreled, the barrels being laid on dry ground and covered deeply with straw. As winter sets in, cover the straw with earth, using just enough to prevent freezing. In cities apples are often placed in a cold attic and allowed to freeze for safe keeping. If they remain frozen until spring, and are then allowed to thaw gradually by the natural lise in temperature, they will not be injured. It appears that all winter varieties cannot be kept in this condition, however. I have known apples to be frozen solid in the barrel, but when placed in a cool cellar and not disturbed until the frost had entirely left them, they came out as bright and hard as ever, and kept as long as those of the same variety which had not been frozen. 


\section{H A P T R X VII.}

PROFITS IN APPLE CULTURE.-SHALL WE PLANT MORE ORCHARDS?-LOSSES FROM THEFT.

There are several reasons why apple culture is not oftener a source of profit, and these reasons fall under two classes: errors in culture and errors in marketing. However well adapted to apple growing the soils and surroundings may be, the industry is bound to be a failure unless uniform good culture is given the orchard. There are many obstacles in the way of producing good and marketable fruit, and the grower must know how to overcome them. These obstacles are poor varieties, too many varieties, poor cultivation, neglect and carelessness in pruning, lack of thinning, insect enemies, etc. Erery effort must be made to secure fruit which is perfect in shape and in surface, firm in texture, and free from insects. But even good fruit will not demand a good price if put upon the market in poor condition. It must not only be sound, but it must be attractive. It is safe to say that not one barrel in twenty which goes into the markets of our large cities is properly packed. People must learn to sort their apples with great care before pritting them upon the market. They must learn to pack them snugly, honestly and attractively.

Even in years of heavy crops, good apples, nicely packed, hring good returns. This is especially the case if the grower has established a demand for his fruit by care in growing, handling and packing. Such a demand is easily secured if under the grower's name, or name and trade- 
mark, a superior and uniform quality of fruit is sold. The following figures represent actual crop sales from a large orchard: In 1877, the crop sold for $\$ 3$ per barrel ; in 1878, \$2.75 and $\$ 3$; in $1879, \$ 3 ; 1880$, $\$ 2, \$ 2.50$ and $\$ 3 ; 1881, \$ 2.75$ and $\$ 3.50 ; 1882, \$ 3$. These figures do not include the culls and cider apples, which were either sold to applicants from local markets or were made into cider or vinegar. It will be observed that the prices averaged about the same for each year. These are not prices made to a few local customers, but the crop was put upon the city market, where it competed with other fruit. It was placed in the hands of competent dealers, however, who were acquainted with the merits of the fruit. The prices are for barrels holding two and three-quarter bushels. This orchard is upon land worth $\$ 60$ an acre, and it will return more money from apples at twenty-five cents a bushel than from wheat at $\$ 1$ a bushel, although if is in a good wheat country. "Leroy," in a recent Philadelphia "Press," makes the following comment upon a very ordinary apple tree: "A prolific tree of salable apples brings much more money from the ground it occupies than would most farm crops. On a medium sized tree thirty years old the owner has every year sold eight to twelve or more bushels of fruit. 'This year the crop was eleven bushels and sold readily at fifty cents a bushel, or $\$ 5.50$. Assuming that the tree occupies fully four square rods of ground, which it does not, here are ${ }^{12} 20$ an acre for a single year's product. This is more than the land itself is worth. Really, this sum, after deducting a small umount for expenses, represent: the interest on the amount which an 
acre of trees equally prolific and profitable would be worth."

In the present season (1884) of cheap fruits even good fall apples, packed in the ordinary careless manner, have brought remunerative prices. Hubbardstons have sold in the Boston markets on an average of $\$ 1.50$ a barrel net, and Gravensteins have brought from $\$ 2$ to $\$ 3$. It is still an open question how to bring the producer and the consumer closer together. Most consumers are willing to pay good prices for good fruit, no matter how great may be the supply of inferior fruit. Diring the season of 1884 Hubbardston apples have retailed rapidly for $\$ 1$ to $\$ 1.50$ per bushel, when the grower received $\$ 1.50$ per barrel for them, and the best Gravensteins have sold all along for $\$ 1.75$ to $\$ 2.75$ and upwards per bushel. The dealer, with less risk, makes a greater profit than the grower.

In years like this prices are injured by the great quantities of poor fruit put upon the market. It is time for growers to understand that there are other ways of disposing of apples advantageously than by lumping them all off to the Bostọn, New York or Chicago market as soon as they are picked. The markets of inland towns are often more satisfactory for limited quantities than are those of the great cities. It is safer to ship only the best grade of green fruit and to make other grades into cider, vinegar or jellies, or to evaporate them. The advent of evaporator's has opened a new source of profit to fruit growers. One bushel of apples will yield from four to eight pounds of evaporated fruit, such as sold in jobbing lots in our market all last winter for twelve and 
fifteen cents per pound. Under the most favorable circumstances one pound of the evaporated fruit will about pay for the cost of evaporating a bushel. Moreover, the skins and cores need not be wasted. A bushel will give about three and a half pounds of skins and cores, and these sell for two and a half and three cents a pound for making into jellies.

Of ordinary apples from seven to twelve bushels are required for a barrel of cider. Wholesale dealers are now selling cider in limited quantities at ten and twelve cents per gallon. At present prices, cider apples certainly ought to bring a fair return bcyond the cost of manufacturing. Cider vinegar, at retail, brings about a half more per gallon than cider, and it is generally in fair demand, though inferior vinegars seriously interfere with its sale. The local demand for cider vinegar is usually good among those who appreciate its superiority. Apple butter is coming into the markets to some extent, and were it manufactured in sufficient quantity to give certainty to a market, it would, no dou!t. soon come into general demand at good prices.

\section{SHALL WE PLANT MORE ORCHARDS?}

This is a perennial question, which presents itself after every season of low prices in fruits, and one which acts as a stumbling-block to the general farmer and fruit grower alike. The impression somehow becomes current that the prices rendered the grower from metropolitan dealers in these years of great plenty should determine the future supply of fruit. 'This is a fallacy which needs correction. The farmer is bound to be undeceived if he 
anticipates a unifom success, one year with another, from any system of husbandry. From this year's markets alone the wheat farmer has more reason than the fruit grower for anticipating an uncertain future, still I doubt if many grain farmers will give up the growing of wheat. The questions, whose answers should have most weight in deciding the matter of planting, relate more to the adaptability of the man to the business, of the soil to the health and productiveness of trees, to market facilities, etc., than to the state of the market in a single year. It should be borne in mind that good fruit is nearly always in good demand.

The most complete failures I erer knew in fruit growing were those connected with men who had no native taste for the occupation, or who attempted too much. While fruit growing is not a difficult branch of husbandry to follow, it nevertheless requires a vigilance and a certain adroitness which are not commanded by all farmers, and which are not readily adaptable to large estates. The bungler and shiftless farmer are entirely out of place in the orchard. Good fruit growers are nearly always good observers; they recognize and study insects, birds and insidious plant diseases; they exercise great care in bandling and marketing their produce. A successful orchard is commonly planted with much thought. Trees are perennial; they ought to last as long as their owner. They cannot be cut down each autumn and a new crop started the next year. It is the lack of a good foundation, a thoughtful, well-pondered beginning, which renders half our orchards unsatisfactory. Almost any fruit grower will tell you that he would have made money by 
laying a better fo:ndation. The orchard which is set in haste this year, will probably be excelled in ten years by one which is thoughtfully planted, three years from now. The fruit grower must be a man of method.

It was said twenty-five years ago that apples would not be worth picking in ten years from that time, and there is record of a farmer in Western New York who cut down an orchard of ten acres because of that supposed fact. 'This same man has since planted an orchard of twentyfive acres, and is said to be getting profitable returns for his land and labor. It is extravagant to suppose that the supply of apples can exceed the demand in this country. The country is settling up much faster than orchards are being grown, and there are large portions of the country in which apples can never be grown, but where they will always be used.

LOSSES FROM THERT.

In some places more fruit is lost from theft than from the combined depredations of injurious insects. It is a trouble, aIso, which is exceedingly difficult to manage. So long as parents neglect to teach that petty larceny of fruit is no less a theft than taking a man's money, so long will the trouble continue. There are always some families in the neighborhood in which such teaching is never heard. These families are commonly the ones who do not attend the meetings of fruit growers, who do not attend church, and who do not take a good paper. It is therefore hard to reach them. It is comparatively easy to check a suirit of pilfering when the offender can be brought to hear mild discussions or 
teachings upon the subject, or when he can be induced to read good agricultural papers. As such offenders cannot be made to go to farmers' meetings or to other public gatherings, however, I have thought that it might be an experiment worth trying to send to them agricultural papers regularly. Let them understand how much of work and of difficulty there is in growing crops, what the rights of the farmer are; in short, get them interested in a progressive agriculture, and it appears to me that some, at least, "would be influenced for the better. For other reasons, also, I have sometimes thought that it would pay an intelligent commmity to circulate agricultural papers among the poor and illiterate families.

The attitude of a grower towards all with whom he may come in contact, will largely determine the extent to which his fruit and regetables will be pilfered. A man who is universally disliked may expect to suffer. I have often observed that college students, by common consent, do not pilfer from a man who is always kind and free-hearted, while their attitude towards a stingy or disagreeable man is quite the opposite. I once knew a man who placed a great picket fence about his orchard. and who kept armed men in it all night, and I also knew many idlers who experienced the keenest delight in getting into that orchard. A neighbor who took no precautions lost less fruit. In a neighboring community the fruit growers posted in public places the law concerning trespass, and they reported good success from the practice. It appears to me that there is no subject more worthy of occasional discussion in farmers' clubs, in the local paper, in the pulpit, in the Sunday school, than 
this. It is not a subject which will bear much malice or personal rebuke. It must be discussed in a mild and thoughtful manner.

\section{H A P T E R X V I I .}

\section{WINTER PREPARATIONS.}

The orchard should not be neglected as soon as the fruit is harvested. During winter, trees are exposed to wind, ice, water, rabbits and mice. Weak or cracked branches are apt to be broken down by wind and ice. All crotches which show a disposition to split should be tied or bolted together. Weak and injured limbs should be tied up or cut off. Small and weak trees should be staked.

During thaws, water will settle in the hollows. See to it that there are no such hollows about the trees. Level culture is the best safeguard against winter and spring injury from water. Where hollows occur, either fill them up, or provide a way for the water to escape.

If the orchard and surrounding fields are kept clear of brush heaps and other rubbish, rabbits will not make much trouble. Slovenly fence rows aiford good wintering places for rabbits. Unless the snow drifts into the branches, these pests will not injure large trees. A good dog is a good remedy for rabbits, but I shonld prefer to employ other means of getting rid of them, and dispense with the dog altogether. I have melted sulphur and poured it over small pieces of cloth, which were fastened 
to sticks and placed promiscuously through the orchard, and rabbits did not annoy me. Blood and various animal substances smeared on the trees will keep rabbits away.

Mice are a worse evil than rabbits. Their work is not often discovered until too late to be avoided. Clean culture is a good preventive of injuries by mice. Mice delight in high grass, which bends under the snow, and in all litter which accumulates about the tree. They are especially fond of corn shocks about trces. If a loose mulch remains about the tree, they will be likely to discover it. Therefore, keep the base of the tree clean. Remove all grass and litter, or cover it up with soil and pack it down firmly. In Northern New England, where the paper birch grows abundantly, it is a favorite practice to peel strips of bark two feet long and place them about the trees. This bark soon curls up tightly about the tree, and protects it. 


\section{CHA P TER XI $\dot{X}$.}

\section{INJURIOUS INSECIS.}

Numerons insects prey upon the apple orchard. In fact, Professor Lintner catalogues one hundred and seventy-six such pests. Fortunately, comparatively few of these are yet seriously troublesome, and it is not probable that many more will become pests over any great extent of territory. There are more species of injurious insects apparent now than there were a balf century ago. This is due in part to the introduction of insects from the Old World, and in part to the taking on of new habits by native insects. The disagreeable apple maggot, which has attracted so much attention of late, was first known as breeding on the wild hawthorns, but it took on a new habit of attacking cultivated apples, and it has thrived upon its new diet.

In order to combat insect enemies the orchardist must acquaint himself with the general natural history of insects, their common habits and the best means of destroying them. He must read and study. He must also be vigilant. He should seek for preventives in preference to remedies. A clean orchard is necessary. Keep down weeds and remove rubbish and do not allow the fencerows to grow up with promiscuous vegetation.

He must destroy the wild food plants of insects. This is a subject which has a very important bearing on fruit growing, and one which; it appears to me, does not receive the attention it deserves. The continued prevalence of injurious insects in some localities where there has. 
been a general concert of action to destroy them, can be accounted for in no other way than by supposing that they breed on wild plants. Many orchardists have found that a hawthorn hedge has been an expensive luxury by breeding apple tree borers and other insects. Now that the disgusting apple waggot lias spread itself over so wide an extent of country, it becomes important that we destroy the wild hawthorns. To those who love the wild plants which decorate our copses and tangles, this destruction of hawthorns and other bushes will come as a hardship; but it is to be remembered that utility must come before beauty. Moreover, those who admire the hawthorns can plant them and keep off the insects. The wild crab breeds the Codlin Moth. The wild cherry. is perhaps the favorite food plant of the destructive Tent Caterpillar.

Not only do some wild plants breed orchard insects, but they are not infrequently the means of causing little known insects to multiply so rapidly as to take on new habits and overrun the farm. I have in mind a painful instance. In Western Michigan a swamp of wild roses bred the rose chafer. The insects were noticed by residents in the vicinity for some years, it is said. The insects multiplied to such an extent that the swamps could no longer hold them, and they overran small fruits and orchards for miles about in the most destructive manner. Over a considerable area these insects have been the most serions of orchard pests for some years.

Information concerning insects is now easily obtained. The scope of these notes allows me to discuss only the most injurious pests, the Borers and the Codlin Moth. 


\section{H A P T E R X X.}

BORERS,

An attack of borers is to be suspected as soon as a tree begins to show a gradual diminution of vigor. If borers are present, one will discover little masses of chips pushed out from small holes about the base or along the trunk of apple, pear and quince trees, or wax at the base of peach trees, or he will observe dead and discolored patches on the bark. The damage done by horers is so permanent in its character that the orchardist should exercise every

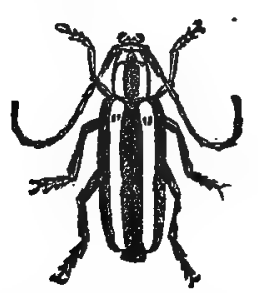

Fig. 14.

BEETLE OF ROUND-HEADED BORER.

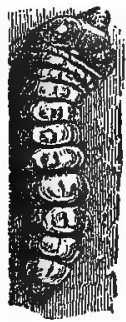

Fig. 15.

THE ROUND-HEADED BORER.

care to prerent an attack. Neatness about the trees will enable the grower to discover an attack before it has done great damage. A wash made after the following recipe, and applied to the tree with a broom or brush, is a general preventive of attacks from borers: Water, one gallon; soft soap, one quart; crude carbolic acid, about one pint.

ROUND-HEADED APPLE TREE BORER.

This insect (Saperda candida) commonly begins its work about the base of the apple, pear or quince tree, although it is occasionally found in the branches. Its presence is indicated, especially after the first year, by the chips which 
are pushed from its burrows. The larva or grub lives three years. When full grown (figure 15) it is about an inch long, nearly cylindrical, whitish or often tinged with yellow. The pretty brown and white striped parent beetle (figure 14) is commonly nocturnal in its habits, and is therefore seldom seen by the casual observer.

If one would know the whole life history of this insect, he will be obliged to watch it three years, and to follow it from an egr laid on the bark, through a tiny opening into the sapwood, through a gradually enlarging channel tending inwards and upwards, and finally reaching its termination just beneath the bark. There the insect would be at the end of nearly three years, a motionless pupa, wrapped in a cocoon of its own chips. During the first year the grab works in the soft sapwood, just underneath the bark, but about the beginning of its second year it enters the hard wood. Sometimes, however, the tunnel is nearly superficial for its whole length. During two winters the insect remains in the tree as a grub, but before the third winter, it has changed into a pupa, and lies in its cocoon until the following spring, when it becomes a beetle. The pupa sometimes transforms into a bcetle before warm weather appears, and the beetle will then lie in the burrow until awakened by the warmth of May or June. It then gnaws a smooth, round hole through the bark, and escapes at night. Evidently aware of the ill repute in which it is held, the beetle hides itself during the day, and at night flies about the orchard, bent upon mischief. It is occasionally met with in the daytime. All through June and July it lingers about the orchard, but before the summer 
is over it is dead. Before its final departure, however, it bas made an ample record. The female has laid her eggs in the crevices of the bark, usually about the base of the apple tree or pear tree or the quince bush. If cultivated fruit trees are not abundant, she has probably sought out their nearest relatives, the Mountain Ash, the June berry and the wild thorns. By early fall, perhaps as early as July, the eggs have hatched, and the young legless grubs have entered upon their work of destruction. It sometimes happens that the tree does not show strong signs of debility for a couple of years or more. In the meantime, it may have been extensively channelled, and limbs an inch and less in diameter may have been tunnelled. Finally, the tree begins to die, or a strong wind breaks it down. When a tree is thus past recovery, it should be burned. Short pieces of limbs may be put into a box, covered with a wire screen, and if the larvæ are well matured, the striped beetles may be secured. In the Eastern States this borer is abundant. It has been my observation that in Michigan and westward it is less common.

\section{PREVENTIVES.}

Attacks of borers can be prevented by a liberal use of the carbolic soap wash. The wash should be applied early in June and again near the last of the month, or early in July. All shreds of rough bark should be removed before the wash is applied. Especial care should be exercised to make a thorough application about the crown of the tree.

A small mound of ashes or lime, placed about the base of the tree in spring, is an old preventive; but as the 
beetle sometiwies lays its eggs on the upper trunk or branches, it is not to be relied upon.

Tying heavy brown paper about the base of the tree for a distance of two or three feet above the ground, and smearing the paper with coal tar is often recommended.

\section{REMEDIES.}

When the chips are discovered, procure a flexible wire, or peel the bark from a small twig and thrust it into the hole. A wire which is setinto a handle will be found convenient. A peculiar pressure will tell you when you have struck the grub. When the grub has once reached the hard wood, it is a barbarous practice to wbittle it out with a jackknife. The grubs are easily killed during the first year after they begin work, especially in the fall. During that time they work just underneath the bark, eating out irregular burrows as large as a half-dollar. If more than one borer should attack the tree, it may be well-nigh girdled the first year. Before the chips of the borer appear, a drop of brown sap may be seen exuding from each hole. One can readily see just where the young borer is, and can kill it by using the point of a knife.

Woodpeckers often destroy many borers while the grub is working just under the bark. I have frequently seen them digging out the borers in winter.

'The beetles secrete themselves in the tree during the day, and they may be jarred down upon sheets in the manner of catching curculios. They are not attracted by lights at night to any extent.

N. S. Smith, Buffalo, N. Y., published a remedy nearly 
thirty years ago, and I transcribe it with the recommendation that if used it be done cautiously: "Make a concave mound of mellow earth around the tree, rising about six inches above the work of the insects. Thoroughly saturate this mound witl a strong salt brine, twice at an interval of four weeks, at any time of the year when the ground is not frozen. Stale beef or pork brine in its full strength is just the thing. The mound of earth holds the liquid in suspension round the tree until, by capillary attraction, it is carried into the holes and borrows' of the insect, where the salt is sure destruction to this ravaging and pestilent enemy. Vary the quantity of the dose with the size of the tree. Be cautious with small trees. Old, large trees, three feet round, may have a pailful at a time. I have revived trees by this application from apparent deatl. Apple trees thirty years old, with their trunks perforated rery badly, are now perfectly healthy, and their wounds are healing over."

A correspondent of the "Horticulturist," 1846, recommends injecting a solution of potash into the holes of the borer by means of a small syringe. Two pounds of potash is to be dissolved in a gallon of water.

A small gouge and a mallet are often used, the wound which is made by the gouge being securely waxed over. This harsh remedy is to be employed only when the grub has burrowed far into the wood, an'd where it is impossible to reach it with the wire or twig.

\section{SPOTTED BORER (Saperda cretata).}

This (figure 16) is closely allied to the preccding, and in its habits is scarcely to be distinguished from that 
insect. It is not generally known. On account of its close resemblance to the Round-headed Borer it has probably been overlooked. It has been observed by Mr. H. Osborn in Iowa, and by Professor A. J. Cook in Michigan. Professor Cools's description of the insect is here quoted :

"Saperda cretata has hardly a mention in our current literature on economic entomology, and yet I find that in Central Michigan it is quite as common and destructive as Saperda candida. * * * * This beetle, like Saperda candida, is from threc-fourths to seven-eighths of an inch

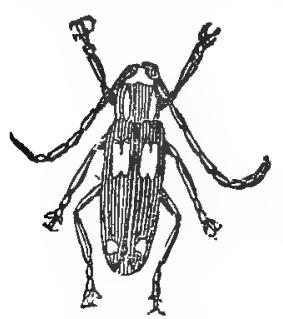

Fig. 16. - SAPERTA URETATA. long, and brown, marked with white, though the white is not so prominent, and, instead of white lines, it is only represented by lines across the thorax and white spots on each elytra or wing cover, one in the middle, notched in both ends, and one near the tip, notched or crescent-shaped on the inner posterior angle. The head, antennæ and legs are all brown, while a broad, brown central stripe extends along the cntire length of the ventral or under surface of the thorax and abdomen. In Saperda candida the head is striped above on each side with white, while the antennæ, legs and entire under surface are white. The cylindrical, footless larva and the pupa are almost entirely alike in both species, as are also the habits. The eggs are laid in June on the trunk and main branches of apple trees, wild crab-apples, June berry and wild thorn."

Four or five years ago Mr. Osborn wrote as follows regarding the habits of the Spotted Borer : 
"The eggs are evidently laid in pairs, half an inch or more apart along the branch, the larvæ of each pair, upon hatching, working in opposite directions around the branch, at first just beneath the bark, but afterward (probably after the first year) ontering the hard wood."

The preventives and remedies recommended for the Round-headed Borer are to be used for this insect.

\section{FLAT-HEADED BORER (Chrysobothris femorata).}

The presence of this borer is usually indicated by dark and dead patches on the bark of apple, pear and peach trees. It is an insect no less pernicious than the old Saperda. 'The grub, with its cnormonsly flattened anterior, usually burrows just underneath the bark, a]though it occasionally enters the hard wood. Its tunnels are flattened, and by this character are at once distinguished from those of the Round-headed Borer. The work of this borer tells sooner upon the tree, and in weakezed

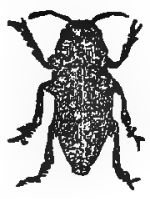

Fig. 17. Fig. 18.-FLATTHE BEETLE, HEADED BORER. trees it is more fatal, than that of the other insect. It usually attacks trees upon the south side, or on the side towards the prevailing winds, or in other places where injuries are apt to occur. It nearly alivays attacks trees which are weakened, such as those recently transplanted or top-grafted. Newly set tress should therefore be watched closely. The eggs of the Chrysobothris are laid on the bark from early June until Angust. The young grub eats through the bark and matures rapidly, for the next spring it transforms 
into a compact and shining dark beetle, as represented in figure 17. These beetles have a coppery lustre underneath, and I bave heard them called " copper bottoms." They vary in size. They are commonly about threefourths of an inch long. In the Middle and Western States this insect is abundant.

Dr. Asa Fitch first described the Flat-headed Borer in 1856 as attacking apple trees. Its appearance in apple trees was at that time so recent that he could not obtain much information concerning it. The insect had long been known as attacking oaks, and it was probably the destruction of these timber trees which caused it to attack the apple tree. As late as Flint's edition of Harris' Injurious Insects (1862) it was not known to attack apple trees in Massachusetts, although it was not uncommon on oaks, and it had been found "upon and under the bark of peach trees."

\section{PREVENTIVES.}

The soap wash recommended for the Round-headed Borer is equally effective here.

I believe that the best preventives of the attacks of the Flat-headed Borer are tidiness about the orchard and good cultivation. I have observed that the borer nearly always attacks neglected trees. Those which have stood in grass for some years, and which have not been properly pruned, are especially i̊able to attack. A smooth, clean, tidy bark is commonly an indication of thriftiness, and borers do not attıck it. If the trunk of the tree crooks abruptly to the northward, the sun beats upon the more exposed point and produces an enfeebled condi- 
tion. At such points, or in other weak places, the borers are nearly always found. The majority of all the trees which I have known to be infested with these borers had crooked trunks.

\section{REMEDIES.}

The Flat-headed Borer is easily destroyed by crushing after the dead bark is removed. 'The bark, being dead, is of no more use to the tree, and it had better be cut off; otherwise it soon beconles loose, and affords a hidingplace for insects. If the denuded surface is large, it should be protected by wax or by cow dung, tied on with cloths. Newly-set trees are soon ruined by an attack, and they should be examined every month from July to October.

C. Baker, in "Kansas Farmer," recommends the use of kerosene oil, freely poured on the bark, as a remedy for borers. 


\section{H A P T E X XI .}

\section{THE CODLIN MOTH.}

The pretty little moth (Carpocapsa pomonella), repre sented at natural size in figure 19, is the parent of the apple worm. It is a European insect, introduced into this country in the early purt of this century. Very few apple growers are acquainted with the moth, Fig. 19.-conas it flies at night. The outer wings are цाN мотн. marked with irregular and ill-defined transverse streaks of gray and brown, and on the end they bear a brown, bronze-streaked spot. The inuer wings and abdomen are light yellowish brown. The moth flies with its body in a nearly perpendicular position. There are many moths or "millers," which, to the unpracticed eye, closely resemble this, and which are confounded with it. Hence arise the erroneous statements that the codlin moths are attracted by lights, and that they lave been captured in great quantities in preparations of sweetened water, etc.

The moth makes its appearance about the time that the apple blossoms appear. A moth lays about fifty eggs, according to Mr. Saunders. A single egg is laid in the "blossom end" of the young apple, and in about a week it hatches, and the young larva eats its way into the apple. In three or four weeks the larva is full grown, and it leaves the apple to find a hiding place under the rough bark, where it may spin its cocoon and make the wonderful transformation into a moth. The second moth of 
the season-the second brood-repeats the operation of the first one, and the second brood of larvæ is hatched. The second larvæ do not transform into moths until the following spring. Now, it so happeus that all moths do not appear at the same time in spring, so that there is a succession of larvæ in each brood. This accounts for the fact that on the same day one may find larva of all sizes.

\section{PREVENTIVE.}

The only preventive with which I am acquainted is a systematic concert of action on the part of all who grow apples to destroy the insects. In fact, it is almost useless, or certainly discouraging, to make war upon any insect nuisance if one's neighbors persist in making no effort in the same direction. This prevention is rather in the nature of a remedy, however.

\section{REMEDIES.}

As there is no method of trapping the moth, we must confine our remedies to the worm or larva. The old remedy is to avail ourselves of the opportunity afforded when the larva leaves the apple and rolls up in its cocoon. Remove the rongh bark, as recommended on page 44, and place a strip of woolen cloth, four or five inches wide, about the trunk. Under this cloth the insects will hide. In warm weather the transformation from the larva to the moth will take place in nine days; in cooler weather the time varies to fifteen days. The bands should be put on early in June, and during warm weather they should be examined about every eight days. Many of the last 
brood will be taken to the cellar with the apples, and they will hibernate in crevices there. I have found them in great numbers under the hoops and between the staves of apple barrels in the cellar. In spring the transformation takes place and the moths escape through the windows. It is therefore very important that the cellar windows and doors should be provided with tine wire screens. Upon these screens the moths can be killed as they endeavor to escape.

The greater number of the worms leave the fruit before it falls. Hogs do not destroy them in quantity, therefore, unless the apples have vrey recently fallen. Under the discussion on picking fruit, page $5 \%$, I have referred to a convenient method of thinning apples by means of a sharp hook (figure 13). If hogs run in the orehard thcy will soon learn to follow the operator and pick up the apples as soon as they fall. Inasmuch as thinning is a necessity to profitable results in most cases, it becomes an economical method of destroying the apple worm. If this practice were generally pursued in connection with the application of bands, and the use of the following remedy, I am confident that this pest would soon be lessened.

A remedy proposed of late is to syringe the trees with a mixture of Paris green and water, very early in the season, while the young apples stand erect. The poison lodges in the "blossom end" and destroys the first brood of worms. Later, when the apples turn downward, the poison is washed out by the rains. T'his remedy was proposed, and its entire success demonstrated, by Professor A. J. Cook, of the Michigan Agricultural College. A tablespoonful of poison to a ga!lon of water is sufficient. 


\section{N D E X.}

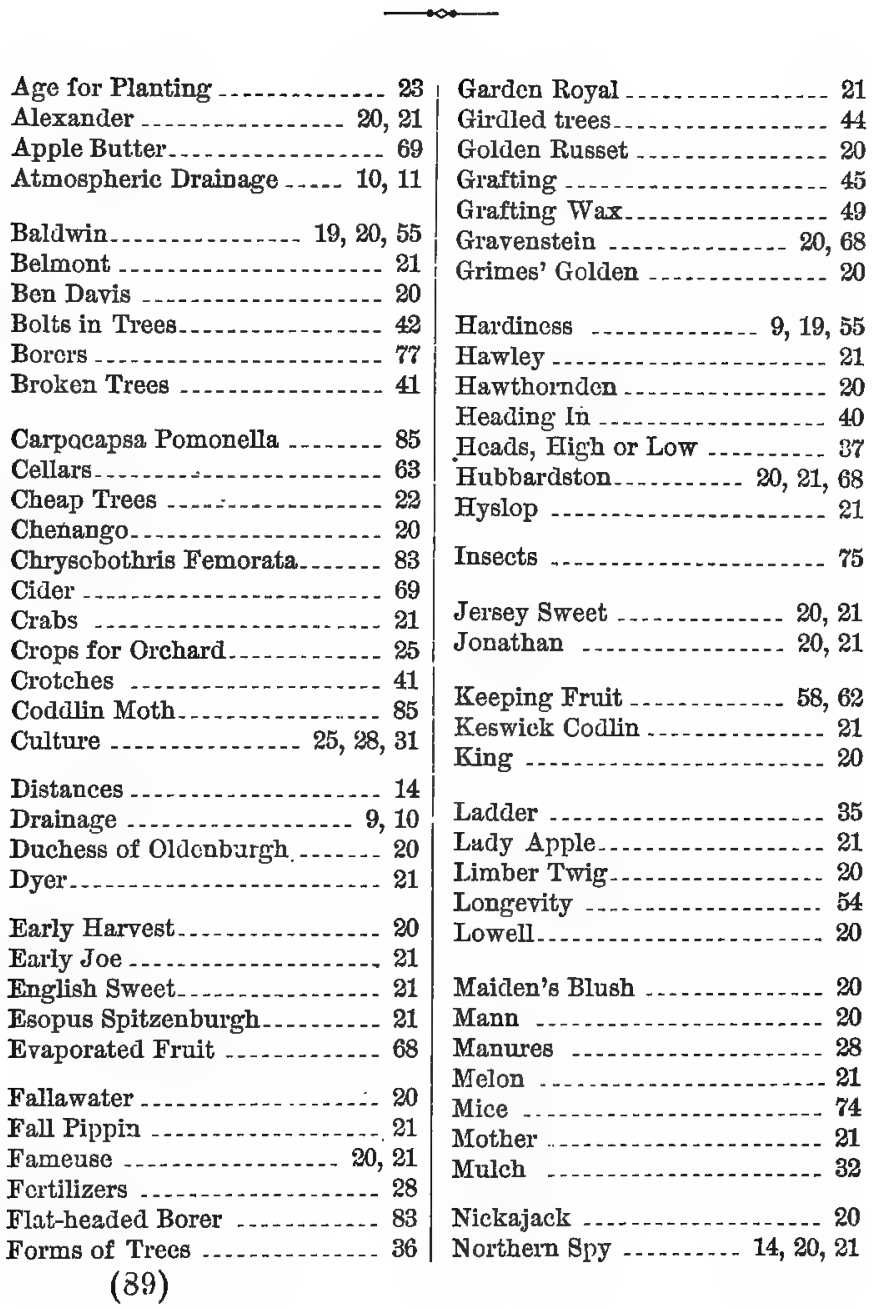


Ohio Nonpareil................. 20

Oldenburgh.................. 20

Packing .................. 59

Peck's Pleasant ............ 20

Picking ................ 55

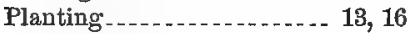

Plowing .................... 24

Pomme Gris ................ 21

Porter ......................... 20

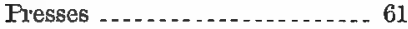

Primate ..................... 20

Productiveness................ 19

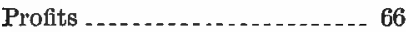

Pruning ….................. 33

Rabbit …

Red Astrachan .............. 20

Red Canada................... 20

Repairing -................. 39

Rhode Island Greening'-. 14, 20,

21,38

Roxbury Russet............... 20

Round-headed Borer .......... 77

Russian Apples ............... 21

St. Lawrence

Saperda Candida............. 77

Saperda Cretata_............. 82

Scraping -.......-........... 44

Setting . . . . .

Shiawassee ................ 20, 21

Smith's Cider ................. 20
Snow Apple................ 20

Sod ....................... 31

Soils ................... 9, 20

Staking -................. 40

Stark _...

Summer Rose................ 21

Swaar . . . .

Bweet Bough ................ 20

Talman \&weet .............. 20

Theft ..................... 71

Tillage ................. 25, 28, 31

Time for Planting............. 16

Tompkins King-.......... 14, 20

Training _............... 39

Transcendent _................. 21

Trimming..................... 33

Twenty Ounce ................. 20

Vandevere .................. 20

Varieties................ 18

Vinegar..................... 69

Wagener-.................. 21

Wash …................ 77

Wax ...................... 49

Whitewashing -............. 45

Whitney -.................. 21

Williams' Favorite ............ 20

Windbreaks .................. 10

Yellow Bellefleur ............. 21

Yellow Newtown Pippin ....... 21 


\section{SENT FREE ON APPLICATION.}

\section{DESCRIPTIVE CATALOGUE}

一: OF :-

\section{RURAL

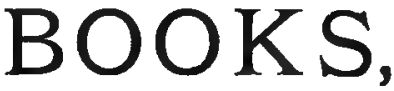

Containing II6 8vo pages, profusely illustrated, and giving full descriptions of nearly 600 works on the following subjects:

FARM AND GaRden,

Fruits, Flowers, ETC.,

Cattle, Sheep, and Swine,

Dogs, Etc., Hurses, Riding, Etc.,

Poultry, Pigeons, and Bees,

Angling and Fishing,

Boating, Canoeing, and Saiming,

Field Sports and Natural History,

Hunting, Shooting, Etc,

Architecture and Building,

Landscape Gardening,

Household and Miscellaneous.

PUBLISHERS AND IMPORTERS.

ORANGE JUDD COMPANY,

$5^{2} \& 54$ Lafayette Place, New York. 


\section{Mushrooms. How to Grow Them.}

For home use fresh Mushrooms are a delicious, highly nutritious and wholesome delicacy; and for market they are less bulky than eggs, and, when properly handled, no crop is more remunerative. Anyone who has an ordinary house cellar, woodshed, or barn cau grow Mushrooms. This is the most practical work on the subject ever written, and the only book on growing Mushrooms ever published in America. 'The whole subject is treated in detail, minutely and plainly, as only a practical man, actively engaged in Mushroom growing, can handle it. The author describes bow le himself grows Mushrooms, and how they are grown for profit by the leadiug market gardeners, and for bome use by the most successful private growers. The book is amply and pointedly illustrated, with engravings drawn from nature expressly for this work. By Wm. Falconer. Is nicely printed and bound in cloth. Price, post-paid.... 1.50

\section{Allen's New American Farm Book.}

The very best work on the subject; comprising all that can be condensed into an available volume. Originally by Richard L. Allen. Revised and greatly enlarged by Lewis F. Allen. Cloth, 12mo... 2.50

\section{Henderson's Gardening for Profit.}

By Peter Henderson. New edition. Entirely rewritten and greatly enlarged. The standard work on Market and Family Gardening. The successful experience of the author for more than thirty years, and his willingness to tell, as he does in this work, the secret of his success for the benefit of others, enables him to give most valuable information. The book is profusely illustrated. Cloth, 12mo_-_ 2.00

\section{Fuller's Practical Forestry.}

A Treatise on the Propagation, Planting, and Cultivation, with a description and the botanical and proper names of all the indigenous trees of the United States, both Evergreen and Deciduous, with Notes on a large number of the most valuable Exotic Species. By Andrew S. Fuller, author of " Grape Culturist," "Small Fruit Culturist," ete.

\section{The Dairyman's Manual.}

By Henry Stewart, author of "The Shepherd's Manual," "Irrigation," etc. A useful and practical work by a writer who is well known as thoroughly familiar with the subject of which he writes.

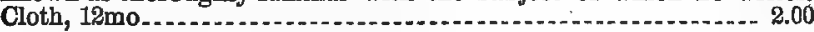

Truck Farming at the South.

A work giving the experience of a successful grower of vegetables or "grain truck" for Northern markets. Esseutial to any one who contemplates entering this promising field of Agriculture. By A. Oemler,

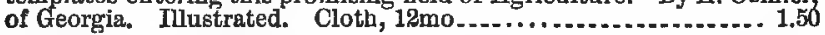

\section{Harris on the Pig.}

New edition. Revised and enlarged by the author. The points of the various English and American breeds are thoroughly discussed, and the great advantage of using thoroughbred males clearly shown. The work is equally valuable to the farmer who keeps but fow pigs, and to the breeder on an extensive scale. By Joseph Harris. Illustrated.

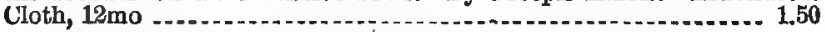

\section{Jones's Peanut Plant-Its Cultivation and Uses.}

A practical Book, iustructing the beginner how to raise good crops of Peanuts, By B. W. Junes, Surry Co., Va. Paper Cover, .... .50 


\section{Barry's Fruit Garden.}

By P. Barry. A standard work on fruit and fruit-trees; the author having had over thirty years' practical experience at the head of one of the largest nurseries in this country. New edition, revised up to date. Invaluable to all fruit-growers. Illustrated. Cloth, 12mo. 2.00

\section{The Propagation of Plants.}

By Apdrew S. Fuller. Illustrated with numerous engravings. An eminently practical and useful work. Describing the process of hybridizing and crossing species and varieties, and also the many differ ent modes by which cultivated plants may be propagated and multi-

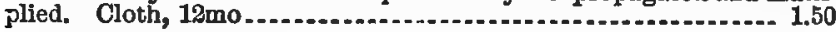

\section{Stewart's Shepherd's Manual.}

A Valuable Practical Treatise on the Sheep. "or American farmers and sheep growers. It is so plain that a farmer, or a farmer's son, who has never kept a sheep. may learn from its pages how to manage a flock suceessfully, and yet so complete that even the experienced shepherd may gather many suggestions from it. The results of personal experience of some years with the characters of the various moderı breeds of sheep, and the sheep-raising capabilities of many portions of our extensive territory and that of Canada-and the careful study of the diseases to which our sheep are chiefly subject, with those by which they may eventually be afflicted through unforeseen accidents-as well as the methods of management called for under our circumstances, are here gathered. By Heni'y Stewart, Llustrated. Cloth, 12mo.... 1.50

\section{Allen's American Cattle.}

Their History, Breeding, and Management. By Lewis F. Allen. This Book will be considered indiepensable by erery breeder of live stock. The large experience of the author in improving the character of American herds adds to the weight of his observations, and has enabled him to produce a work which will at once make good his claims as a standard authority on the subject. New and revised edition. Illustrated. Cloth, 12mo......... 250

\section{Fuller's Grape Culturist.}

By. A. S. Fuller. This is one of the very best of works on the culture of the hardy grapes, with full directions for all departments of propagation, culture, etc., with 150 excellent engravings, illustrating planting, training, grafting, etc. Cloth, 12mo_..50

\section{White's Cranberry Culture.}

ConTENTs:-Natural History.-History of Cultivation.-Choice of Location.-Preparing the Ground.-Planting the Vines.-Management of Meadows.-Flooding-Enemies and Difficulties Overcome.-Picling.- Keeping,-Profit and Loss.-Letters from Practical Growers.- Insects Injurious to the Cranberry. By Joseph J. White. $\Lambda$ practical grower. Ilustrated. Cloth, 12mo. New and revised editicn-1.25

\section{Herbert's Hints to Horse-Keepers.}

This is one of the best and most popular works on the Horse in this country. A Complete Manual for Horsemen, embracing: How to Breed a Horse; How to Buy a Horse; How to Break a Horse; How to Use a Horse; How to Feed a Horse; How to Physic a Horse (Allopathy or Homopathy); How to Groom a Horse; How to Drive a Horse; How to Ride a Horse, ete. By the late Henry William Herbert (Frank Forester). Beautifully Illustrated, Cloth, 12mo... 1.75 


\section{Henderson's Practical Floricalíure.}

By Peter Henderson. A guide to the successful propagation and cultivation of llorists' plants. The work is not one for llorists and gardeners only, but the amateur's wants are constantly kept in mind, and we have a very complete treatise on the cultivation of flowers under glass, or in the onen air, suited to these who grow flowers for pleasure as well as those who make them a matter of trade. The work is characterized by the same radical common sense that marked the author's "Gardening for Protit," and it holds a high place in the estimation of lovers of agriculture. Beautifully illustrated. New and enlarged edition. Cloth, 12mo

\section{Harris's Talks on IIanures.}

By Joseph Harris, M. \$., author of "Walks and Talks on the Farm," "Harris on the Pig." etc. Revised and enlarged by the author. A series of familiar and practical talks between the author and the deacon, the cloctor, and other neighbors, on the whole subject of manures and fertilizer's; including a chapter specially written for it by Sir John Bennet Lawes, of Rothamsted, England. Cloth, 12mo_...... 1.75

\section{Waring's Draining for Profit and Draining for Health.}

This book is a very complete and practical treatise, the directions in which are plain, and easily followed. The subject of thorough farm drainage is discussed in ull its bearings, and ulso that more extensive land drainage by which the sanitary condition of any district may be greatly improved, even to the banishment of fever and ague, typhoid and malarious fever. By Geo. E. Waring, Jr. Illustrated, Cloth 12mo.

\section{The Practical Rabbit-Keeper.}

By Cuniculus. Illustrated. A comprehensive work on keeping and raising Rabbite for pleasure as well as for profit. The book is abun dantly illustrated with all the various Courts, Warrens, Hutches, Fencing, etc., and also with excellent portraits of the most important

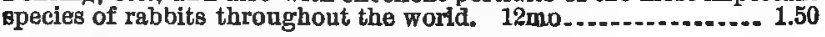

\section{Quinby's New Bee-Keeping.}

The Mysteries of Bee-keeping Explained. Combining the results of Fifty Year's' Experience, with the latest discoveries and inventious, and presenting the most approved methods, forming a complete work.

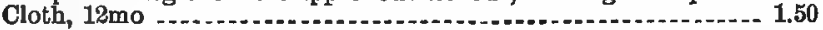

\section{Profits in Poultry.}

Useful and Ornamental Breeds and their Profitable Management. This excellent work contains the combined experience of a number of practical men in all departments of poultry raisjug. It is profusely illustrated and forms an unique ard important addition to our poultry lit-

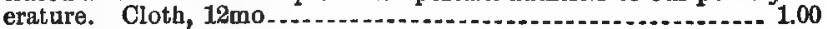

\section{Barn Plans and Outbuildings.}

Two Hundred and Fifty-seven Illustrations. A most Valuable Work, full of Ideas, Hints, Suggestions, Plans, ete., for the Construction of Barns and Outbuildings, hy Práctical writers. Chapters are devoted, among other subjects, to the Economic Erection and Uee of Barns. Grain Barns, House Barns, Cattle Barns, Sheep Barns, Corn Houscs, Smoke Houses, Ice Houses, Pig Pens, Granaries, etc. There ar'e likewive chapters upon Bird Houses, Dog Houses, Toul Bheds, Ventilators, Roofs and Roofing, Doors and Fastenings, Work Shops, Ponltry Houses, Manure Sheds, Barn Yards, Root Pits, etc. Recently pub-

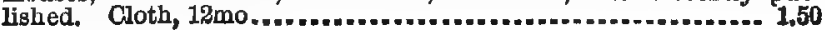


Parsons on the Rose.

By Samuel B. Parsors. A treatise on the propagation, culture, and history of the rose. New and revised edition. In his work upon the rose, Mr. Parsous has gathered up the curious legends concerning the flower, and gives us an idea of the esteem in which it was held in former times. A simple garden classitication has been adopted, aud the leading varieties under each cluss enumerated and briefly described. The chapters on multiplicstion, cultivation, and training are very full, and the work is altogether one of the mcst complete before the public. Illustrated. Cloth, 12mo.....................1.10

\section{Heinrich's Wirdow Flower Garden.}

The author is a practical florist, and this enterprising volume cmbodies his personal experiences in Window Gardening during a long period. New and enlarged edition. By Julius J. Heinrich. Fully

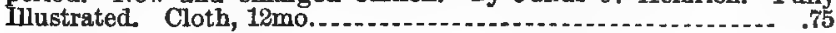

Liantard's Chart of the Age of the Domestic Animals. Adopted by the United States Army. Enables one to accurately determine the age of horses, cattle, sheep, dogs, and pigs............ .50

\section{Pedder's Land Measurer for Farmers.}

A convenient Pocket Companion, showing at once the contents of any piece of land, when its length and width are known, up to 1,500 feet either way, with various other useful farm tables. Cloth, 18mo;

\section{Hos to Plant and What to Do with the Crops.}

With other valuable bints for the Farm, Garden and Orchard. By Mark W. Johuson. Illustrated. Contents : Times for Suwing Seeds : Covering Seeds; Field Crops; Garden or Vegetable Seeds, Sweet Herbs, etc.; Tree Seeds ; Flower Seeds ; Frait Trees ; Distances Apart for Fruit Trees and Shrubs ; Profitable Farming ; Green or Manuring Crops ; Root Crops ; Forage Plants ; Wbat to do with the Crops ; The Rotation of Crops ; Varieties ; Paper Covers, post-paid.......... .50

\section{Your Plants.}

Plain and Practical Directions for the Treatment of Tender and Hardy Plants in the House and in the Garden. By James Sheehan. The above title well describes the character of the work- "Plain and Practical." The author, a commercial forist and gardener, has endeavored, in this work, to answer the many questions asked by his customers, as to the proper treatment of plants. The book shows all through that its author is a practical man, and he writes as one with a large store of experience. The work better meets the wants of the amateur who grows a few plants in the window, or has a stnall flower Gurden, than a lirger treatise intended for those who cultivate plants upon a moro cxtended-scale. Price, post-paid, paper covers ................40

\section{Husmann's American Grape-Growing and Wine-Making.}

By George Husmann of Taleoa vineyards, Napa, California. New and enlarged edition. With contributions from well-known grape-growers, giving a wide range of experience. The author of this book is a recognized uthority on the subject. Cloth, 12mo............... 1.50

\section{The Scientific Angler.}

A general and instructive work on Artistic Angling, by the late David Foster. Complied by his Bons. With an Introductory Chapter and Copinus Foot Notes, by Willam C. Harris, Editor of the "Anerican

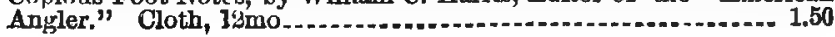




\section{Keeping One Cow.}

A collection of Prize Essays, and selections from a number of other Essays, with editorial notes, suggestions, etc. This book gives the latest information, and in a clear and condensed form, upon the management of a single Milch Cow. Illustrated with full-page engravicgs of the most famous dairy cows. Recently published. Cloth, 12 mo ....... . . . . 1.00

\section{Law's Veterinary Adviser}

A Guide to the Prevention and Treatment of Disease in Domestic Animals. This is one of the best works on tbis subject, and is especially designed to supply the need of the busy American Farmer, who cau rarely arail himself of the advice of a Scientific Veterinarian. It is brought up to date and treats of the Prevention of Disease, as well as of the Remedies. By Prof. Jas. Law. Cloth, Crown 8vo..... 3.00

\section{Guenon's Treatise on Milch Cows.}

A Treatise on the Bovine Species in General. An entirely new translation of the last edition of this popular and instructive book. By Thos. J. Hand, Secretary of the American Jersey Cattle Club. With over 100 Illustrations, especially engraved for this work. Cloth, 12mo.

\section{The Cider Maker's Handbook.}

1.00

A complete guide for malking and keeping pure cider. By J. M. Trowbridge. Fully Illustrated. Cloth, 12mo....... 1.00

\section{Long's Ornamental Gardening for Americans.}

A treatise on Beautifying Homes, Rural Districts, and Cemeteries. A plain and practical work at a moderate price, with numerous illustrations, and instructions so plain that they may be readily followed. By Elias A. Long. Landscape Architent. Illustrated. Cloth, $12 \mathrm{mo}$.

\section{The Dogs of Great Britain, America and Other Countries.}

New, enlarged and revised edition. Their breeding, training and management, in health and disease; comprising all the essential parts of the two standard works on the dog, by "Stonehenge," thereby furnishing for $\$ 2$ what once cost $\$ 11.25$. Contains Lists of all Premiums given at the last Dog Shows. It Describes the Best Game and Hunting Grounds in America. Contains over One Hundred Beautiful Engravings, embracing most noted Dogs in both Continents, making together, with Chapters by American Writers, the most Complete Dog

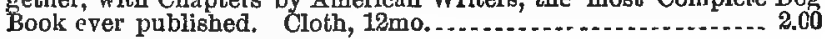

\section{Stewart's Feeding Animals.}

By Elliot $W$. Stewart. A new and valuable practical work upon the laws of animal growth, specially applied to the rearing and feeding horses, cattle, diary cows, sheep and swine. lllustrated. Cloth, 12mo.

\section{How to Co-operate.} 2.00

A Manual for Co-operators. By Herbert Myrick. This book describes the how rather than the wherefore of eo-operation. In other words it tells how to manage a co-operative store, farm or factory, and co-operative dairying, banking and fire insurance, and co-operntive farmers, and women's exchanges for" both buying and selling. The directions given are based on the actual experience of successful co-operative enterprises in all parts of the United States. The character and usefulness of the book commend it to the attention of all men and women who desire to better their condition. 12mo, Cloth............. 1.50 


\section{Batty's Practical Taxidermy and Home Decoration.}

By Joseph H. Batty, taxidermist for the government surveys and many colleges and museums in the United States, An entirely new and complete as well as authentic work on taxidermy-giving in detail full directions for collecting and mounting animals, birds, reptiles, fish, insects, and general objects of natural history. 125 illustrations. Cloth, 12mo.

1.50

Stewart's Irrigation for the Farm, Garden, and Orchard.

New and Enlarged Edition. This work is offered to those American Farmers, and olher cultivators of the soil, who from painful experience can readily appreciate the losses which result from the scarcity of water at critical periods. By Henry Stewart. Fully illustrated.

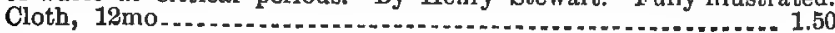

\section{Johnson's How Crops Grow.}

New Euition, entirely rewritten. A Treatise on the Chemical Composition, Structure, and Life of the Plant. Revised Edition. This book is a guide to the knowledge of agricultural plants, their composition, their structure, and modes of development and growth; of the complex organization of plants, and the use of the pal'is; the germination of seeds, and the food of plants obtained both from the air and the soil. The book is an invaluable one to all real students of agriculture. With numerous illustrations and tables of analysis. . By Prof. Samuel W. Johnson, of Yale College. Cloth, 12mo .........00

\section{Johnson's How Crops Feed.}

A treatise on the Atmosphere and the Soil, as related in the Nutrition of Agricultural Plants. "The volume-the companion and complement to "How Crops Grow,"-has been welcomed by those who appreciate scientific aspects of agriculture. Illustrated. By Prof. Samuel W. Johnson. Cloth, 12mo

\section{Warington's Chemistry of the Farm.}

Treating with the utmost clearness and conciseness, and in the most popular manner possible, of the relations of Chemistry to Agriculture, and providing a welcome manual for those, who, while not having time to systematically stady Chemistry, will gladly bave such an idea as this gives them of its relation to operations on the farm. By $R$.

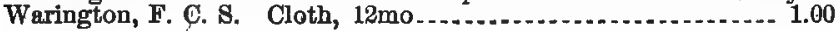

\section{French's Farm Drainage.}

The Principles, Process, and Effects of Draining Land, with Stones, Wood, Ditch-plows, Open Ditehes, and especially with Ties; includIng Tables of Rainfall, Evaporation, Filteration, Excavation, Capacity of Pipes, cost and number to the acre. By Judge French, of New

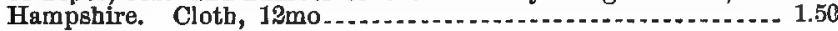

\section{Hunter and Trapper.}

The best modes of Hunting and Trapping are fully explained, and Foxes, Deer, Bears, etc., fall into his traps readily by following his directions. By Halsey Thrasher, an old and experienced sportsman. Cloth, 12mo

\section{The American Merino. For Wool or for Mutton.}

A practical and most valuable work on the selection, care, breeding and diseases of the Merino sheep, in all sections of the the United States. It is a full and exhaustive treatise upon this one breed of wheep. By Stephen Powers. Cloth, 12mo.................... 1.50 


\section{Armatage's Every Man His Own Horse Doctor.}

By Prof. George Armatige, M. R. C. V. S. A valuable and comprehensive guide for both the professional and general reader with the fullest and latest information legarding all diseases, local injuries, lameness, operations, poisons, the dispensatory, etc , etc., with practical anatomical and surgical Illustrations. New Edition. Together with Blaine's "Veterinary Art," and numerous recipes. One large 8vo. volume, 830 pages, half morocco ............................ 7.

\section{Dadd's Modern Horse Doctor.}

Containing Practical Observations on the Causes, Nature, and Treatment of Diseases and Lameness of Horses-embracing recent and improved Methods, according to an ealightened system of Veterinary Practice, for Preservation and Restoration of Health. Illustrated.

By Geo. H. Dadd, M. D. V. S., Cloth, 12mo.....................

\section{The Family Horse.}

Its Stabling, Care, and Feeding. By Geo. A. Martin. A Practical Manual, full of the most useful information. Illustrated. Cloth,

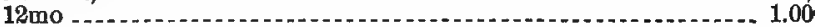

\section{Sander's Horse Breeding.}

Being the general principles of Heredity applied to the Business of Breeding Horses and the Management of Stallions, Brood Mares and Foals. The book embraces all that the breeder should know in regard to the selection of stock, management of the stallion, brood mare, and foal, and treatment of diseases peculiar to hreeding animals. By ${ }^{\mathbf{}} \mathrm{J}$.

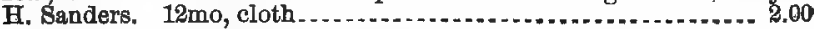

\section{Coburn's Swine Husbandry.}

New, revised and enlarged edition. The Breeding, Rearing and Management of Swine, and the Prevention and Treatment of their Diseases. It is the fullest and freshest compendium relating to Swine Breeding yet offered. By F. D. Coburn. Cloth, 12mo...... 1.75

\section{Dadd's American Cattle Doctor.}

By George H. Dadd, M. D., Veterivary Practitioner. To help every man to be his own cattle-doctor; giving the necessary information for proserviug the heslth and curing the diseases of oxen, cows, sheep, and swine, with a great variety of original recipes, and valuable information on farm and dairy management. Cloth, 12mo....... 1.50

\section{Silos, Ensilage, and Silage.}

A practical treatise on the Ensilage of Fodder Corn. Containing the most recent and authentic information on this important subject, by Mauly Miles, M.D., F.R.M.S. Illustrated. Cloth 12mo...... .50

\section{Broom Corn and Brooms.}

A Treatise on Raising Broom-Corn and Making Brooms on a small or Large Scale. Illustrated. 12mo. Cloth cover..............

\section{American Bird Fancier.}

Or how to breed, rear, and care for Song and Domestic Birds. This valuable and important little work for all who are interested in the keeping of Song Birds, has been revised and enlarged, and is now a complete manual upon the subject. All who own valuable birds, or wish to do so, will find the new Fancier indispensable. New, revised and enlarged edition. By D. J. Browne, and Dr. Fuller Walker. Illustrated, paper cover........50 


\section{Armatage's Every Man Fis Own Cattle Doctor.}

The Veterinary Cyclopedia-Embracing all the practical information of value heretofole published on the Diseases of Cattle, Sheep, and Swine, together with the latest and best information regarding all known diseases up to the present time. Compiled and edited by that eminent authority, Prof. George Armatage, M. R. C. V. S. One large octavo volume, 894 pages, with upwards of 350 practical illustrations, showing forms of disease and treatment, Half moroceo. 7.50

\section{Onions-How to Raise them Profitably.}

Being the Practical Details, from Selection of Seed and Preparation of Ground to Harvesting and Marketing the Crop, given. very plainly by Seventeen Practical Onion Growers of long experience residing in different parts of the country. No more valuable work of its aize was ever issued. Paper cover, 8vo ...........20

\section{Tobacco Culture-Full Practical Details.}

This useful and valuable work contains full details of every procesa from the Selection and Preparation of the Beed and Soil to the Harvesting, Curing and Marketing the Crop, with illustrative engravings of the operations. The work was prepared by Fourteen Experienced Tobacco Growers, residing in different parts of the country. It also contains notes on the Tobacco Worm, with illustrations, 850, . .25

\section{Hop Culture.}

Plain directions given by ten experienced cultivators. Revised, enlarged and edited by A. S. Fuller. Forty engravings..., 30

Flax Culture.

A very valuable work, containing full directions, from selection of ground and seed to preparation and marketing of crop, as given by a number of experienced growers, 8vo . . . . . 30

\section{Potato Pests.}

No Farmer can aff̣ord to be without this little book. It gives the most complete account of the Colorado Beetle any where to be found, and includes all the latest discoveries as to the habits of the insect and the various means for its destruction. It is well illustrated, and exhibits in a map the spread of the insect since it left its native home. By Prof. C. V. Riley. Paper cover........50

\section{Home Fishing and Home Waters.}

By Seth Green. The Utilization of Farm Streams; Management of Fish in the Artificial Pond; Transportation of Eggs and Fry, etc.

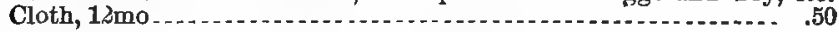

\section{Reed's House Plans for Everybody.}

By S. B. Reed. This useful volume meets the wants of persons of moderate means, and gives a wide range of design, from a dwelling costing $\$ 250$ up to $\$ 8,000$, and adapted to farm, village and town residences. Nearly all of these plans have been tested by practical wurkings. One feature of the work imparts a value over any similar publication of the kind that we have seen. It gives an estimate of the quantity of every article used in the construction, and the cost of each article at the time the building was erected or the design made. Even if prices vary from time to time, one can, from these data, ascertain within a few dollars the probable cost of constructing any one of the buildings here presented. Profusely illustrated. Cloth, black and gold, $12 \mathrm{mo}$ 


\section{Gregory on Cabbages-How to Grow Them.}

A Practical Treatise on Cabbage Culture, giving full details on every point, inclnding Keeping and Marketing the Crop. By James J. H. Gregory. Paper cover, 12mo......,

Gregory on Carrots, Mangold-Wurtzels, etc.

How to raise them, how to keep them, and how to feed them. By J.J. H. Gregory. Paper Cover, 12mo... .30 Gregory on Onion Raising.

What kinds to raise, and the way to raise them. By J. J. F. Gregory. Paper cover, 12mo. 30

Gregory on Squashes.

This Treatise, which no Farmer or Gardener ought to be without, tells all about selecting the soil for squashes; how much Manure is necessary; how to prepare and Plant; about Hoeing and Cuitivating; Setting of the Fruit; Ripeniog, Gathering, Storing, Care during Winter, etc. By J. J. H. Gregory. Paper cover, 12mo........ .30

\section{Hog-Raising and Pork-Making.}

By Rufus Bacon Martin. The hog is reared for the money that is in him, and he represents either a profit or loss to his owner accorting to the treatment he receives. This pamphlet gives the personal researeh and experience of the author, contains many raluable suggestions, and answers many of the questions that arise in the business of hograising. Paper, 12mo... 40

\section{Fulton's Peach Culture.}

This is the only practical guide to Peach Culture on the Delaware Peninsula, and is the best work upon the subject of peach growing for those who would be successful in that culture in any part of the country. It has been thoroughly revised and a large portion of it rewritten, by Hon. J. Alexander Fulton, the author, bringing it down to date. Cloth, $12 \mathrm{mo} . . .50$

Silk Culture.

A Handbook for Silk-Growers. By Mrs. C. E. Bamford. ConTENTS-Chapter I. The Mulberry--II. Gathering the Leaves.III. The Cocoonery.-IV. Eggs of the Silk Worm Moth.-V. Feeding the Silk Worms.-VI. Moulting.-VII. Spinning.-VII. The Coconns.-IX. The Moths of the Silk Worm.-X. Varieties of Silk Worms.-XI. Diseases of the Silk Worm.-XII. Reeling.-XIII. Chemistry of Silk.-XIV. Miscellaneous. Paper, 12mo. Price, postpaid.

Treats' Injurious Insects of the Farm and Garden. By Mrs. Milary Treat.

An original investigator who has added much to our knowledge of both Plants and iusects, and those who are familiar with Darwin's works are aware that he gives her credit for important observation and discoveries. New and Enlarged Edition. With an Illustrated Chapter on Beneficial Insects. Fully illustrated. Cloth, 12mo

\section{Fuller's Small Fruit Culturist.}

By Andrew S. Fuller. Rewritten, enlarged, and bronght fully up to the present time. The book covers the whole ground of propagating smail fruits, their culture, varieties, packing for market, etc. It is very finely and thoroughly illustrated, and makes an admirable companion to "The Grape Culturist," by the same well known author. 





